Sección Agrícola / Agriculture

Artículo de revisión / Review paper

\title{
Arthropod pests and their management, natural enemies and flora visitors associated with castor (Ricinus communis), a biofuel plant: a review
}

\author{
Artrópodos plaga y su manejo, enemigos naturales y visitantes florales asociados a la \\ higuerilla (Ricinus communis), un cultivo bioenergético: revisión
}

\author{
GUILLERMO LÓPEZ-GUILLÉN'ㄹ JAIME GÓMEZ-RUIZ²; JUAN F. BARRERA³
}

\begin{abstract}
${ }^{1}$ Ds. C. Instituto Nacional de Investigaciones Forestales, Agrícolas y Pecuarias (INIFAP), Campo Experimental Rosario Izapa, C. P. 30780, Tuxtla Chico, Chiapas, Mexico, lopez.guillermo@inifap.gob.mx, https://orcid.org/0000-0001-7858-9984. ${ }^{2}$ Ds. C. El Colegio de la Frontera Sur, C. P. 30700, Tapachula, Chiapas, Mexico,jgomez@ecosur.mx, https://orcid.org/0000-0002-9704-9761. ${ }^{3}$ Ph. D. El Colegio de la Frontera Sur, C. P. 30700, Tapachula, Chiapas, Mexico, jbarrera@ecosur.mx, https://orcid.org/0000-0002-8488-7782.
\end{abstract}

Corresponding author: Guillermo LópezGuillén, Ds. C. Instituto Nacional de Investigaciones Forestales, Agrícolas y Pecuarias (INIFAP), Campo Experimental Rosario Izapa, C. P. 30780, Tuxtla Chico, Chiapas, Mexico,lopez.guillermo@inifap.gob. $m x$, https://orcid.org/0000-0001-7858-9984.

Suggested citation:

LÓPEZ-GUILLÉN, G.; JAIME GÓMEZRUIZ, J.; BARRERA, J. F. 2020. Arthropod pests and their management, natural enemies and floral visitors associated with castor (Ricinus communis), a biofuel plant: a review. Revista Colombiana de Entomología 46 (1): e8604. https://doi.org/10.25100/socolen. v46i1.8604

Received: 23-Feb-2018

Accepted: 2-Aug-2019

Published: 31-Aug-2020

Revista Colombiana de Entomología ISSN (Print): 0120-0488

ISSN (On Line): 2665-4385

https://revistacolombianaentomologia.univalle.edu.co/

Open access

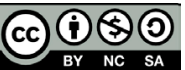

Publishers:

Sociedad Colombiana de Entomología SOCOLEN (Bogotá, D. C., Colombia) http://www.socolen.org.co Universidad del Valle (Cali, Colombia) http://www.univalle.edu.co/

(C) 2020 Sociedad Colombiana de Entomología - SOCOLEN y Universidad del Valle - Univalle
Abstract: Interest in bioenergetic crops, such as the castor oil plant Ricinus communis (Euphorbiaceae), for production of biodiesel has increased in recent years. In this paper, phytophagous arthropods, their natural enemies and floral visitors associated with this plant in the world are reviewed. Despite its insecticidal properties, arthropods have been reported feeding on $R$. communis plants. The arthropod pests of $R$. communis damage all parts of the plant, including the seeds, where some toxic compounds are even more concentrated. In the scientific databases, we found reports of 193 arthropods associated to $R$. communis in different parts of the world. This information obtained in the scientific databases was concentrated in a database and analyzed according to the coevolutive hypothesis, which allows us to predict that the greatest wealth and abundance of phytogenic arthropods is found in the center of origin by $R$. communis. According to this review, Achaea janata, Spodoptera litura, Edwardsiana flavescens, Liriomyza trifolii, L. sativae, Spilosoma obliqua, Cogenethes punctiferalis, Oxyrhachis taranda, and Helicoverpa armigera are the most devastating pests in Asia. In Africa, Agrotis ipsilon, S. exigua, Nezara viridula, Trialeurodes ricini, and Tetranychus urticae were mentioned as the most important. In Central and South-America, Phyllophaga sp., Agrietes sp., Erinnyis ello, N. viridula, Corythucha gossypii, Falconia antioquiana, and S. marima are reported as pests of economic importance. The most commonly reported natural enemies of some of these arthropod pests were species of Bacillus thuringiensis, B. cereus, $B$. popilliae, Trichogramma achaeae, T. chilonis, T. minutum, T. australicum, T. dendrolimi, T. pretiosum, T. evanescens, Microplitis rufiventris, M. maculipennis, M. ophiusae, Telenomus remus, T. proditor, Stethorus siphonulus and S. histrio. Apis mellifera is recorded as the main insect pollinator of $R$. communis. Pest management methods used against the arthropod pests of $R$. communis include biological, ethological, mechanical, cultural, genetic, and chemical control.

Keywords: Castor-oil plant, biodiesel, pests, entomophagous organisms, pollinators.

Resumen: El interés por los cultivos bioenérgeticos, tales como Ricinus communis (Euphorbiaceae) para producir biodiesel ha aumentado en años recientes. En este documento se hace una revisión sobre los artrópodos fitófagos, enemigos naturales y visitantes florales asociados a esta planta en el mundo. A pesar de las propiedades insecticidas de $R$. communis, existen registros sobre artrópodos que se alimentan de ella. Los artrópodos plaga de $R$. communis dañan toda la planta, incluso las semillas, donde se localizan compuestos tóxicos más concentrados. En las bases de datos científicas, se encontró registro de 193 artrópodos asociados a $R$. communis en diferentes partes del mundo. Esta información se concentró en una base de datos y se analizó de acuerdo con la hipótesis coevolutiva, la cual permite predecir que la mayor riqueza y abundancia de artrópodos fitófagos, se encuentra en el centro de origen de $R$. communis. De esta revisión se desprende que entre las plagas más devastadoras en Asia se encuentran Achaea janata, Spodoptera litura, Edwardsiana flavescens, Liriomyza trifolii, L. sativae, Spilosoma obliqua, Cogenethes punctiferalis, Oxyrhachis taranda y Helicoverpa armigera. En África, las plagas más importantes son Agrotis ipsilon, S. exigua, Nezara viridula, Trialeurodes ricini y Tetranychus urticae. Entre las plagas de importancia económica que se reportan en Centro y Suramérica, están Phyllophaga sp., Agrietes sp., Erinnyis ello, $N$. viridula, Corythucha gossypii, Falconia antioquiana y $S$. marima. Los enemigos naturales de algunas plagas comúnmente reportados fueron Bacillus thuringiensis, B. cereus, B. popilliae, Trichogramma achaeae, T. chilonis, T. minutum, T. australicum, T. dendrolimi, T. pretiosum, T. evanescens, Microplitis rufiventris, M. maculipennis, M. ophiusae, Telenomus remus, T. proditor, Stethorus siphonulus y $S$. histrio. Se registra a Apis mellifera como el insecto más polinizador de $R$. communis. Los métodos de manejo de plagas contra artrópodos de $R$. communis incluyen control biológico, etológico, mecánico, cultural, génetico y químico.

Palabras clave: Higuerilla, biodiesel, plagas, entomófagos, polinizadores. 


\section{Introduction}

The castor-oil plant, Ricinus communis L., is an oleaginous plant belonging to the Euphorbiaceae family, which comprises 280 genera. This species has been cultivated for more than 6000 years on the Asian continent, and more recently on the African and American continents (Govaerts et al. 2000; Salihu et al. 2014). R. communis is a non-edible plant, mainly used in chemical, pharmaceutical, and automobile industries, where it has numerous applications (Savy 2005; Barnes et al. 2009; Severino et al. 2010). All parts of this plant contain lectin ricin - one of the most potent lethal natural poisons known - but is particularly concentrated in the seeds and pods (Audi et al. 2005).

In recent years, $R$. communis oil has acquired importance as a biofuel, due to the possibility of its use in producing biodiesel (Baldwin and Cossar 2009; César and Batalha 2010). $R$. communis is distributed in tropical and subtropical regions and is also adaptable to temperate zones (Lima et al. 2011). The principal producer countries of $R$. communis seeds are India, China, and Mozambique; whereas the countries with the highest consumption of the products of this plant are Holland, Japan, and Italy (Faostat 2015). India, China, and Brazil contribute approximately $95 \%$ of the world production of seeds (Sailaja et al. 2008).

Ricinus communis seeds are outstanding for their high oil content, between 40 and $60 \%$, compared with sunflower (Helianthus annuus L.) seeds with 38 to $48 \%$, soybean (Glycine $\max$ (L.) Merr.) between 18 and $19 \%$, moringa (Moringa oleifera L.) with 14 to $24 \%$, neem [Azadirachta indica (Juss)] between 17 and $39 \%$, and cotton (Gossypium hirsutum L.) with 15 to $19 \%$ (Kittock and Williams 1970; Severino et al. 2006; Nass et al. 2007; Baldwin and Cossar 2009; Martín et al. 2010), a characteristic that makes this plant very attractive as a source of biofuel, particularly biodiesel.

The extensive cultivation of varieties and hybrids of $R$. communis under different management practices has made the plant vulnerable to biotic and abiotic factors. $R$. communis plants may lose leaves, seeds and pods for different reasons: damage by pests, diseases, wind, hail, traffic of machinery, and inappropriate use of herbicides and defoliation (Severino et al. 2010). Even though a castor-oil plant can recover from severe defoliation, the damage suffered by the leaves may reduce the production. It is estimated that for $1 \mathrm{~m}^{2}$ of lost leaf area, seed production diminishes by $37.8 \mathrm{~g}$ and oil production by 24.4 g (Lakshmamma et al. 2009; Lakshmi et al. 2010; Severino et al. 2010). Continuous sowing of $R$. communis in the same areas, as well as the lack of intercropping has increased the occurrence of pests and diseases. There are reports that more than 100 species of insects in different parts of the world feed on $R$. communis and can cause serious damage (Barteneva 1986; Kolte 1995). In India, for example, insect pests caused losses in seed production from 35 to 50 $\%$ (Kolte 1995). Integrated pest management programs are therefore important to prevent losses that can affect the economy of producer-countries.

The present literature reviewed focuses on the phytophagous arthropods associated with $R$. communis in different parts of the world, as well as, their natural enemies and floral visitors. The information was obtained through extense search of scientific literature on these subjects published in the Web of Science database, Ebsco database and Google Scholar, using appropriate key words (e.g. 'insects on Ricinus communis' 'arthropods on
Ricinus communis', 'pests of Ricinus communis or castor-oil'); the search was conducted until January 2019. Afterwards, the information collected was analyzed from the perspective of the co-evolutionary hypothesis following the approach of literature review analysis of arthropod herbivory on physic nut (Jatropha curcas L.) conducted by Lama et al. (2015). Specifically, we set out to answer the following questions regarding the arthropods associated with $R$. communis: (1) What is the diversity of arthropod taxa associated with this plant? (2) In what geographic area does the greatest richness of associated arthropod species occur? (3) What are the parts of the plant most preferred by the herbivorous arthropods? and (4) What mouthpart classes of the arthropods associated with $R$. communis can be identified? According to the co-evolutionary hypothesis, it would be expected to find greater richness of native arthropod species in Asia and Africa, the origin area of $R$. communis, in comparison with those areas where this plant has been introduced or cultivated more recently.

\section{Phytophagous arthropods associated with $R$. communis}

Ricinus communis has been considered tolerant and/or resistant to pest attack due to the toxic compounds present in different parts of the plant. Some of the most common compounds found in this plant species are ricin, ricinine, $\mathrm{N}$-demethylricinine, flavonoids, gallic acid, gentisic acid, coumaric acid, syringic acid, cinnamic acid, vanillic acid and rutin, and allergen proteins such as Ric c1 and Ric c3 (Usha Rani et al. 2006; Gahukar 2010; Vandenborre et al. 2011; Usha Rani and Pratyusha 2014). Some of these are toxic compounds that may even have insecticidal or antifeedant properties against insect pests of other crops (Rossi et al. 2012; Amoabeng et al. 2014; Dinesh et al. 2014). Despite the insecticidal properties of $R$. communis, there are reports of arthropods that feed on several parts of this plant. Ricinine, for example, one of its main alkaloids that has shown insecticidal effect on some insect pests of other plants (Bigi et al. 2004; Liu and Li 2006; Rossi et al. 2012) does not have any detrimental effect on certain specialist phytophagous insects that are common pests of $R$. communis, such as Achaea janata (L., 1758) (Lepidoptera: Noctuidae), Spodoptera litura (F., 1775) (Lepidoptera: Noctuidae) and others (Prabhakar et al. 2003; Usha Rani and Pratyusha 2014). This is due to the presence of enzymes in the midgut of these insects that are able to degrade toxins and thus breakdown the plants' natural defenses (Yasur et al. 2009; Usha Rani and Pratyusha 2014).

The arthropod pests of $R$. communis damage all parts of the plant, including the seeds, where some toxic compounds such as lipases, the alkaloid ricinine (including the protein ricin) and glycosides of ricinoleic, isoricinoleic, stearic and dihydroxystearic acids are even more concentrated (Jena and Gupta 2012). The type of pest and damage varies from place to place; some pests of $R$. communis can be present in different regions. Table 1 presents information published in the literature on arthropods that attack $R$. communis.

According to Table 1, $59 \%$ of the arthropod species feed on foliage, $20 \%$ on roots and seedlings, $17 \%$ on flowers, fruits and seeds, and $5 \%$ on stems and branches. The low percentage of arthropods feeding on seeds and roots can be explained in part by the high concentration of ricinine in these parts of the plant (Salihu et al. 2014). To feed on seeds and roots, these arthropods have had to develop highly efficient mechanisms of detoxification (Yasur et al. 2009). 
Table 1. Order, family and geographical distribution of the phytophagous arthropod species that attack cultivated Ricinus communis.

\begin{tabular}{|c|c|c|c|c|}
\hline Order & Family & Species & $\begin{array}{c}\text { Geographical } \\
\text { distribution }\end{array}$ & References \\
\hline \multicolumn{5}{|c|}{ Roots and seedlings } \\
\hline \multirow[t]{6}{*}{ Coleoptera } & Curculionidae & Protostropus spp. & Africa & Salihu et al. (2014) \\
\hline & Elateridae & Agriotes sp. & Costa Rica & Anónimo (1991) \\
\hline & Scarabeidae & Amphimallon solstitialis (Linnaeus, 1758) & Russia & Arkhangel'Skii and Romanova (1930) \\
\hline & & Holotrichia consanguinea Blanchard, 1850 & India & Gahukar (2018) \\
\hline & & Phyllophaga sp. & $\begin{array}{l}\text { Colombia and } \\
\text { Costa Rica }\end{array}$ & Anónimo (1991); Londoño-Zuluaga (2008) \\
\hline & & $\begin{array}{l}\text { Holochelus aequinoctialis (Herbst, 1790) } \\
\text { [= Rhizotrogus aequinoctialis (Herbst, 1790)] }\end{array}$ & Russia & Arkhangel'Skii and Romanova (1930) \\
\hline Diptera & Agromyzidae & Liriomyza trifolii (Burgess, 1880) & India & Anjani et al. (2007) \\
\hline \multirow[t]{5}{*}{ Lepidoptera } & Noctuidae & Agrotis ipsilon (Hüfnagel, 1766) & Colombia and Egypt & $\begin{array}{l}\text { Mona et al. (2005); } \\
\text { Saldarriaga Cardona et al. }(2011)\end{array}$ \\
\hline & & Helicoverpa zea (Boddie, 1850) & USA & Wene (1933) \\
\hline & & Spodoptera frugiperda (J. E. Smith, 1797) & Colombia & Saldarriaga et al. (2011) \\
\hline & & Spodoptera marima (Schaus, 1904) & Brazil & Ribeiro and Costa (2008) \\
\hline & Sphingidae & Erinnyis ello (Linnaeus, 1758) & Brazil & Ribeiro and Costa (2008) \\
\hline \multirow[t]{3}{*}{ Orthoptera } & Gryllidae & Brachytrupes spp. & Africa & Salihu et al. (2014) \\
\hline & Pyrgomorphidae & Chrotogonus spp. & Africa & Salihu et al. (2014) \\
\hline & & Zonocerus variegatus (Linnaeus, 1758) & Africa & Salihu et al. (2014) \\
\hline Isoptera & Termitidae & Odontotermes obesus (Rambur, 1842) & India & Gahukar (2018) \\
\hline \multicolumn{5}{|c|}{ Leaves } \\
\hline Coleoptera & Curculionidae & $\begin{array}{l}\text { Naupactus glaucus Perty, } 1832 \\
{[=\text { Pantomorus glaucus }(\text { Perty, 1830) }]}\end{array}$ & Brazil & Cavalcante et al. (1974) \\
\hline \multirow[t]{3}{*}{ Diptera } & Agromyzidae & Liriomyza sativae Blanchard, 1938 & China & Zhang et al. (2006) \\
\hline & & Liriomyza subpusilla Frost, 1943 & USA & Wene (1933); Parkman et al. (1989) \\
\hline & & Liriomyza trifolii (Burgess, 1880) & India & Galande et al. (2005) \\
\hline \multirow[t]{16}{*}{ Hemiptera } & Aleyrodidae & Bemisia tabaci (Gennadius, 1889) & Costa Rica and Africa & Anónimo (1991); Salihu et al. (2014) \\
\hline & & $\begin{array}{l}\text { Trialeurodes ricini (Misra, 1924) } \\
(=\text { Trialeurodes rara Singh, 1931) }\end{array}$ & India and Egypt & $\begin{array}{l}\text { Idriss et al. (1997); Sarma et al. (2005); } \\
\text { Abdullah and Martin (2007); Raghavaiah (2011) }\end{array}$ \\
\hline & Aphrophoridae & Ptyelus grossus (Fabricius, 1781) & Uganda & Darling (1946) \\
\hline & Cicadellidae & $\begin{array}{l}\text { Amrasca }(\text { Amrasca) biguttula }(\text { Ishida, 1913) } \\
\text { [= Amrasca biguttula biguttula (Ishida, 1912)] }\end{array}$ & India & Sharma and Singh (2002); Raghavaiah (2011) \\
\hline & & Agallia sp. & Spain & Durán et al. (2010) \\
\hline & & $\begin{array}{l}\text { Edwardsiana flavescens (Fabricius, 1794) } \\
{[=\text { Empoasca flavescens }(\text { (Fabricius, 1794)] }}\end{array}$ & India & $\begin{array}{c}\text { Jayaraj (1964); Sarma et al. (2005); } \\
\text { Lakshmi et al. (2005); Jyothsna et al. (2009) }\end{array}$ \\
\hline & & $\begin{array}{l}\text { Empoasca (Empoasca) solana Delong, } 1931 \\
(=\text { Empoasca solana Delong, 1931) }\end{array}$ & USA & Wene (1933) \\
\hline & & Empoasca sp. & Costa Rica & Anónimo (1991) \\
\hline & & Empoasca sp. & Africa & Salihu et al. (2014) \\
\hline & & $\begin{array}{l}\text { Jacobiasca furcostylus (Ramakrishnan y } \\
\text { Menon, 1972) }\end{array}$ & India & Parmar et al. (2006) \\
\hline & Miridae & Falconia antioquiana Carvalho, 1987 & Colombia & Saldarriaga Cardona et al. (2011) \\
\hline & & $\begin{array}{l}\text { Polymerus cognatus (Fieber, 1858) } \\
\text { (= Poeciloscytus cognatus Fieber, 1858) }\end{array}$ & Russia & Arkhangel'Skii and Romanova (1930) \\
\hline & Pentatomidae & Acrosternum pallidoconspersum (Stål, 1858) & Egypt & Jannone (1952) \\
\hline & & Nezara viridula (Linnaeus, 1758) & Costa Rica and Egypt & Jannone (1952); Anónimo (1991) \\
\hline & Pseudococcidae & $\begin{array}{l}\text { Paracoccus marginatus Williams and } \\
\text { Granara de Willink, } 1992\end{array}$ & Cuba & Martínez et al. (2005) \\
\hline & Tingidae & Corythucha gossypii (Fabricius, 1794) & $\begin{array}{l}\text { USA, Colombia, } \\
\text { Mexico, and Cuba }\end{array}$ & $\begin{array}{l}\text { Miller and Nagamine (2005); } \\
\text { Londoño-Zuluaga (2008); Saldarriaga Cardona } \\
\text { et al. (2011), López-Guillén et al. (2012) }\end{array}$ \\
\hline \multirow[t]{4}{*}{ Lepidoptera } & Arctiidae & Amsacta moorei Butler, 1876 & India & Sarma et al. (2005) \\
\hline & & Amsacta albistriga Walker, 1864 & India & Sarma et al. (2005) \\
\hline & & Pericallia ricini (Fabricius, 1775) & India & $\begin{array}{c}\text { Mathur et al. (1994); Neelanarayanan and } \\
\text { Indira (2010) }\end{array}$ \\
\hline & & Spilosoma obliqua Walker, 1855 & India and Pakistan & $\begin{array}{l}\text { Singh and Grewal (1982); Khattak et al. (1991); } \\
\text { Sarma et al. (2005) }\end{array}$ \\
\hline
\end{tabular}


... cont.

$\begin{array}{llcc}\text { Dalceridae } & \text { Anacraga citrinopsis Dyar, 1927 } & \text { Brazil } & \text { Lourenção } \text { et al. (1989) } \\ \text { Limacodidae } & \text { Parasa lepida } \text { Cramer, 1799 } & \text { India } & \text { Raghavaiah (2011) } \\ \text { Lymantriidae } & \text { Dasychira sp. } & \text { Africa } & \text { Salihu et al. (2014) }\end{array}$

Euproctis fraterna Moore, 1883

India

Noctuidae Achaea janata (Linnaeus, 1758)

India, USA,

and China

Helicoverpa armigera (Hübner, 1803-1808)

India and USA

Spodoptera cosmioides (Walker, 1858)

Brazil

Spodoptera exigua (Hübner, 1808)

Egypt

Spodoptera litura (Fabricius, 1775)

Spodoptera ornithogalli (Guenée, 1852)

[= Spodoptera marima (Schaus, 1904)]

Spodoptera sp.

Paul et al. (2000); Suganthy (2010)

Hua (1984); Delaya et al. (1985); Basappa and Lingappa (2001); Mau and Kessing (2007)

Wene (1933); Ribeiro and Costa (2008)

$\begin{array}{ll}\text { Nymphalidae } & \begin{array}{l}\text { Ariadne merione Cramer, 1779 } \\ \text { (= Ergolis merione Cramer, 1779) }\end{array}\end{array}$

India and Pakistan

Bavaresco et al. (2003)

Ribeiro and Costa (2008)

Lohar et al. (1997); Usha Rani and Rajasekharreddy (2009)

Brazil

Ribeiro and Costa (2008)

Costa Rica

India

Anónimo (1991)

Saturniidae Samia ricini (Drury, 1773)

Egypt, India,

and Brazil

El-Shaarawy et al. (1975); Negreiros et al. (1998)

Rothschildia jacobaeae Walker, 1855

Brazil

Ribeiro and Costa (2008)

\begin{tabular}{lll}
\hline Orthoptera & Acrididae & $\begin{array}{l}\text { Chrotogonus (Chrotogonus) trachypterus } \\
\text { robertsi Kirby \& W. F., } 1914 \text { (= Chrotogo }\end{array}$
\end{tabular}

robertsi Kirby \& W. F., 1914 (= Chrotogonus robertsi Kirby \& W. F., 1914)

Thysanoptera Thripidae

Retithrips syriacus (Mayet, 1890)

India

Sarma et al. (2005)

Scirtothrips dorsalis Hood, 1919

India

Sarma et al. (2005)

Zaniothrips ricini Bhatti, 1967

India

Patel et al. (2009)

Eutetranychus orientalis (Klein, 1936)

India

Daniel et al. (1983)

Acarina Tetranychidae

Eutetranychus sp.

Ahuja (1994)

Tetranychus piercei McGregor, 1950

India

Raghavaiah (2011)

Tetranychus urticae Koch, 1836

[= Tetranychus telarius (Linnaeus, 1758)]

China

Lui and Lui (1986)

Morocco and India

Tarsonemidae

Polyphagotarsonemus latus (Banks, 1904)

Belgium

Cangardel (1954); Rajasekhar et al. (1999); Raghavaiah (2011)

\begin{tabular}{|c|c|c|c|c|}
\hline & Tarsonemidae & Polyphagotarsonemus latus (Banks, 1904) & Belgium & Heungens and Degheele (1986) \\
\hline \multicolumn{5}{|c|}{ Stems and branches } \\
\hline \multirow[t]{2}{*}{ Coleoptera } & Buprestidae & Sphenoptera sp. & Africa & Salihu et al. (2014) \\
\hline & Tenebrionidae & Blapstinus sp. & USA & De Ong (1918) \\
\hline Hemiptera & Membracidae & Oxyrhachis taranda (Fabricius, 1798) & India & Ali et al. (2006) \\
\hline Lepidoptera & Cossidae & $\begin{array}{l}\text { Strigocossus capensis (Walker, 1856) } \\
\text { [= Xyleutes capensis (Walker, 1856)] }\end{array}$ & Africa & Salihu et al. (2014) \\
\hline \multicolumn{5}{|c|}{ Flowers, fruits and seeds } \\
\hline \multirow[t]{2}{*}{ Coleoptera } & Anobiidae & Lasioderma serricorne (Fabricius, 1792) & India and Africa & Hussain and Khan (1966); Salihu et al. (2014) \\
\hline & Tenebrionidae & Tribolium castaneum (Herbst, 1797) & Africa & Salihu et al. (2014) \\
\hline \multirow[t]{5}{*}{ Hemiptera } & Cicadellidae & Empoasca sp. & Costa Rica & Anónimo (1991) \\
\hline & Miridae & Eurystylus sp. & Africa & Salihu et al. (2014) \\
\hline & & Helopeltis sp. & Africa & Salihu et al. (2014) \\
\hline & Pentatomidae & Nezara viridula (Linnaeus, 1758) & Costa Rica, and USA & Anónimo (1991); Golden and Follett (2006) \\
\hline & Scutelleridae & Calidea sp. & Africa & Salihu et al. (2014) \\
\hline \multirow[t]{7}{*}{ Lepidoptera } & Crambidae & $\begin{array}{l}\text { Conogethes punctiferalis (Guenée, 1854) } \\
\text { [= Dichocrocis punctiferalis (Guenée, 1854)] }\end{array}$ & India and Australia & $\begin{array}{c}\text { Anonymous (1913); Sharma et al. (1995); } \\
\text { Jyothsna et al. (2009); Patel and Patel (2009); } \\
\text { Hedge et al. (2009) }\end{array}$ \\
\hline & Noctuidae & Achaea janata (Linnaeus, 1758) & $\begin{array}{l}\text { India, USA, and } \\
\text { China }\end{array}$ & $\begin{array}{l}\text { Hua (1984); Delaya et al. (1985); } \\
\text { Basappa and Lingappa (2001); } \\
\text { Mau and Kessing (2007) }\end{array}$ \\
\hline & & Heliothis sp. & Costa Rica & Anónimo (1991) \\
\hline & & Helicoverpa armigera (Hübner, 1803-1808) & India, and USA & $\begin{array}{l}\text { Wene (1933); Geetha et al. (2003); } \\
\text { Satyanarayana and Sing (2003) }\end{array}$ \\
\hline & & Spodoptera sp. & Costa Rica & Anónimo (1991) \\
\hline & Pyralidae & $\begin{array}{l}\text { Cadra cautella }(\text { Walker, } 1863) \\
{[=\text { Ephestia cautella }(\text { Walker, } 1863)]}\end{array}$ & Africa & Salihu et al. (2014) \\
\hline & Tortricidae & $\begin{array}{l}\text { Thaumatotibia leucotreta (Meyrick, 1913) } \\
\text { (= Cryptophlebia leucotreta Meyrick, 1913) }\end{array}$ & Africa & Salihu et al. (2014) \\
\hline
\end{tabular}


A total of 76 species of phytophagous arthropods associated to cultivated plants of $R$. communis is found worldwide (Table 1). Before the present literature review, the report was of 60 species (Raoof et al. 2003). The arthropods reported in Table 1 belong to eight orders and 38 families; $40 \%$ of these species belong to Lepidoptera, $27 \%$ to Hemiptera, $14 \%$ to Coleoptera and $19 \%$ to other orders. The species that belong to Lepidoptera, Hemiptera and Coleoptera represent $81 \%$ of the total. These phytophagous arthropods are distributed geographically in Asia (39\%), America (34\%), Africa (25\%) and Europe (2\%). As it was supposed, it was not uncommon to find that the greatest richness of arthropods associated to $R$. communis occurred in Asia and Africa, continents considered as the center of origin of this plant (Govaerts et al. 2000). $63 \%$ of the species had mandibulate mouthparts (Lepidoptera, Coleoptera, Orthoptera, Isoptera and Diptera) and $37 \%$ were piercingand-sucking mouthpart classes (Hemiptera, Thysanoptera and Acarina).

Of the pests listed in Table 1, the castor semilooper $A$. janata, the tobacco caterpillar $S$. litura, the green leafhopper Edwardsiana flavescens (F., 1794) [=Empoasca flavescens (F., 1794)] (Hemiptera: Cicadellidae), the serpentine leafminer Liriomyza trifolii Burgess, 1880, the vegetable leafminer L. sativae Blanchard, 1938 (Diptera: Agromyzidae), the Bihar hairy caterpillar Spilosoma obliqua Walker, 1855 (Lepidoptera: Arctiidae), the shoot and capsule borer Conogethes punctiferalis (Guenée, 1854) [= Dichocrocis punctiferalis (Guenée, 1854)] (Lepidoptera: Crambidae), the cowbug Oxyrhachis taranda (F., 1798) (Hemiptera: Membracidae), and the cotton bullworm Helicoverpa armigera (Hübner, 1803-1808) (Lepidoptera: Noctuidae), among others, are the most devastating pests in Asia. In Africa, the black cutworm Agrotis ipsilon (Hüfnagel, 1776), the armyworm S. exigua (Hübner, 1808) (Lepidoptera: Noctuidae), the stink bug Nezara viridula (L., 1758) (Hemiptera: Pentatomidae), the castor bean whitefly Trialeurodes ricini (Misra, 1924) (= Trialeurodes rara Singh, 1931) (Hemiptera: Aleyrodidae), the red spider mite Tetranychus urticae Koch, 1836 [= Tetranychus telarius (Linnaeus, 1758)] (Acarina: Tetranychidae), among others, are mentioned as the most important. In Central and South-America, the white grub Phyllophaga sp. (Coleoptera: Scarabaeidae), Agrietes sp., Erinnyis ello (F., 1794) (Lepidoptera: Sphingidae), N. viridula, the cotton lace bug Corythucha gossypii (Fabricius, 1794) (Hemiptera: Tingidae), the sucking bug Falconia antioquiana Carvalho, 1987 (Hemiptera: Miridae), S. marima (Schaus, 1904) (Lepidoptera: Noctuidae) and others, are reported as pests of economic importance for $R$. communis (Varón et al. 2010; Saldarriaga Cardona et al. 2011; López-Guillén et al. 2012).

The principal pests in Brazil are $N$. viridula, the leafhopper Empoasca spp., some defoliator larvae including S. frugiperda Smith (Lepidoptera: Noctuidae), A. janata, and $A$. ipsilon, and mites such as T. urticae, and T. ludeni Zacher, 1913 (Acarina: Tetranychidae) (Soares et al. 2001; Ribeiro and Costa 2008). In Colombia, C. gossypii is mentioned as the pest of greatest economic importance in $R$. communis crops (Varón et al. 2010). In Mexico, C. gossypii, $N$. viridula, and Tetranychus spp. are reported as the main potential pests of $R$. communis (López-Guillén et al. 2012) (Table 1).

\section{Phytophagous arthropods found on noncultivated R. communis}

There are reports of phytophagous insects mostly found in noncultivated $R$. communis plants, isolated plants, as well as, in more or less clustered plants or plants growing in urban and suburban areas, and in disturbed landscapes of Egypt, India, Spain, Uganda, USA and other countries (Oshaibah et al. 1986; Singh et al. 1991; Jacob et al. 2000; Pons et al. 2002; Ylla et al. 2008; Boland 2016; Egonyu et al. 2017).

Table 2 presents a total of 20 species of phytophagous arthropods associated with non-cultivated plants of $R$. communis in the world. These species belong to five orders and 16 families. $60 \%$ of the arthropod species belong to Lepidoptera (30 \%) and Hemiptera (30\%), while 40\% belong to Coleoptera $(20 \%)$ and other orders $(20 \%)$. The species that belong to Lepidoptera, Hemiptera and Coleoptera represent $80 \%$ of the total. $59 \%$ of the arthropod species registered in Table 2 are distributed geographically in Asia (32 $\%$ ) and Africa (27\%), while $41 \%$ are registered in America (32\%) and Europe (9\%). $60 \%$ of the species of arthropods are mandibulate mouthpart (Lepidoptera, Coleoptera, and Orthoptera) and $40 \%$ are piercing-and-sucking mouthpart (Hemiptera and Acarina).

Such insects were observed feeding on leaves of $R$. communis plants, and even though some species have been reported as pests of $R$. communis in other countries, most of them cause no considerable damage. However, they have the potential of becoming pests of $R$. communis if it is cultivated as a monoculture or, $R$. communis could be a plant host for important pests as the invasive ambrosia beetle Euwallacea sp. (Coleoptera: Curculionidae) (Boland 2016; Egonyu et al. 2017). Among these potential pests are insect and mite species of various families of Lepidoptera, Hemiptera, Orthoptera, and others (Table 2).

\section{Pollinator insects and floral visitors in $R$. communis}

Ricinus communis is a monoecious cross-pollinating plant, cultivated as a hybrid in India, Brazil, China, and other countries because they produce better yields than pure lines or varieties (Moll et al. 1962; Birchler et al. 2003; Reif et al. 2007). Several studies demonstrate that certain species of pollinator insects may improve seed production of $R$. communis. For example, it is mentioned that Apis mellifera (L., 1758) (Hymenoptera: Apidae) contributes to increasing $R$. communis crop productivity by incrementing fruit numbers as well as oil content in seeds (Freitas and Cruz 2010).

Among the pollinator insects of $R$. communis, A. mellifera is recorded as the main pollinating insect. It is also mentioned that this insect feeds on the nectar produced by the plant's extrafloral nectar glands (Rizzardo et al. 2012; Waters et al. 2014). A. mellifera is the principal pollinating insect of $R$. communis, and laboratory work has demonstrated that the pollen of this plant reduces bee survival (Junior et al. 2011). According to these studies, expansion of $R$. communis as a crop in the semiarid region of Brazil for biodiesel production represents a risk for the native and domestic bees used for honey production.

As shown in Table 3, a total of 36 species of pollinator insects and floral visitors of non-cultivated plants of $R$. communis is found in the world. These species belong to four orders and 16 families. $25 \%$ of the species belong 
Table 2. Order, family and geographical distribution of the phytophagous arthropod species found on non-cultivated Ricinus communis.

\begin{tabular}{|c|c|c|c|c|}
\hline Order & Family & Species & $\begin{array}{l}\text { Geographical } \\
\text { distribution }\end{array}$ & References \\
\hline \multicolumn{5}{|l|}{ Leaves } \\
\hline \multirow[t]{4}{*}{ Coleoptera } & Bostrichidae & Prostephanus truncatus (Horn, 1878) & Mexico & Bourne-Murrieta et al. (2014) \\
\hline & Chrysomelidae & Diabrotica graminea Baly, 1886 & Puerto Rico & Woloott (1917) \\
\hline & Scarabaeidae & $\begin{array}{l}\text { Lepadoretus sinicus Burmeister, } 1855 \\
\text { (=Adoretus sinicus Burmeister, 1855) }\end{array}$ & USA & McQuate y Jameson (2011) \\
\hline & Scolytidae & Euwallacea sp. & Uganda and USA & Boland (2016); Egonyu et al. (2017) \\
\hline \multirow[t]{6}{*}{ Hemiptera } & Aleyrodidae & Aleurodicus dispersus Russell, 1965 & Cape Verde & Monteiro et al. (2005) \\
\hline & Cicadellidae & $\begin{array}{l}\text { Amrasca }(\text { Amrasca }) \text { biguttula }(\text { Ishida, 1913) } \\
{[=\text { Amrasca devastans (Distant, 1918)] }}\end{array}$ & India & Jacob et al. (2000) \\
\hline & & $\begin{array}{l}\text { Empoasca (Empoasca) kerri Singh-Pruthi, } 1940 \\
\text { (=Empoasca kerri Pruthi, 1940) }\end{array}$ & India & Singh et al. (1991); Jacob et al. (2000) \\
\hline & & $\begin{array}{l}\text { Empoasca (Empoasca) motti Singh-Pruthi, } 1940 \\
\text { (=Empoasca motti Singh-Pruthi, 1940) }\end{array}$ & India & Jacob et al. (2000) \\
\hline & Flatidae & Metcalfa pruinosa (Say, 1830) & Spain & Pons et al. (2002) \\
\hline & Miridae & Apolygus lucorum (Meyer-Dür, 1843) & China & Lu et al. (2010) \\
\hline \multirow[t]{6}{*}{ Lepidoptera } & Arctiidae & Amsacta moorei Butler, 1876 & India & Singh et al. (1989) \\
\hline & Cosmopterigidae & $\begin{array}{l}\text { Pyroderces rileyi }(\text { Walsingham, 1882) } \\
\text { (= Sathrobrota rileyi Walsingham, 1882) }\end{array}$ & Egypt & Oshaibah et al. (1986) \\
\hline & Lymantriidae & Euproctis lunata Walker, 1855 & Bangladesh & Islam et al. (1988) \\
\hline & Noctuidae & Agrotis ipsilon (Hüfnagel, 1766) & Egypt & Younis (1992) \\
\hline & Pyralidae & Phycita diaphana (Staudinger, 1870) & Spain & Huertas Dionisio (2002); Ylla et al. (2008) \\
\hline & Tortricidae & $\begin{array}{l}\text { Thaumatotibia leucotreta (Meyrick, 1913) } \\
\text { (= Cryptophlebia leucotreta Meyrick, 1913) }\end{array}$ & South Africa & Kirkman and Moore (2007) \\
\hline Orthoptera & Acrididae & Melanoplus differentialis (Thomas, 1865) & USA & Spain (1940) \\
\hline \multirow[t]{3}{*}{ Acarina } & Tetranychidae & Eutetranychus banksi (McGregor, 1914) & USA & McGregor (1914) \\
\hline & & Eutetranychus orientalis (Klein, 1936) & Palestine and Egypt & Klein (1936) \\
\hline & & $\begin{array}{l}\text { Tetranychus gloveri Banks, } 1900 \\
\text { (= Tetranychus quinquenychus } \text { McGregor, 1914) }\end{array}$ & USA & McGregor (1914) \\
\hline
\end{tabular}

to Lepidoptera (19\%) and Hemiptera (6\%), while $75 \%$ belong to Hymenoptera $(67 \%)$ and Diptera (8\%). $55 \%$ of the arthropod species registered in Table 3 are distributed geographically in Asia (33\%) and Africa (22\%), while $45 \%$ are registered in America; no records were found for Europe.

In Mexico, Cameroon, USA, India, and Brazil, entomophagous Hymenoptera, as well as several species of Lepidoptera, Diptera, and Hemiptera have been reported to feed on nectaries and flowers of $R$. communis; however, only A. mellifera has been reported as a pollinator. Therefore, it is necessary to carry out studies on pollination and floral ecology in order to determine if there are other insect pollinators of $R$. communis that should be protected or may be used to increase crop yield (Table 3 ).

Some pests can affect pollinators through herbivory. In the case of $R$. communis, Wäckers et al. (2001) showed that plants damaged by larvae of Spodoptera littoralis (Boisd., 1833) (Lepidoptera: Noctuidae) increased the total amount of nectar produced by extrafloral nectaries compared to undamaged plants. De Sibio and Rossi (2016) found a similar result for the herbivory of $S$. frugiperda on $R$. communis. The secretion of carbohydrates through extrafloral nectaries is considered an indirect strategy of plant defense because it serves to attract parasitoids and predators (Heil 2008). Unlike floral nectaries, extrafloral nectaries do not participate in pollination, however, in plants pollinated by insects, extrafloral nectaries can negatively affect the effectiveness of pollination by distracting pollinators away from floral nectaries or when the ants that are attracted by the nectar attack the floral visitors (Wäckers et al. 2001; Turlings and Wäckers 2004).

\section{Natural enemies of the pests of $R$. communis}

Among the natural enemies of the key pests of cultivated $R$. communis, there are parasitoids, predators, and entomopathogens such as fungi, bacteria, nematodes, and viruses, which are used as biological control agents or have been found parasitizing, depredating, or naturally infecting some pests of the crop. An extensive list of natural enemies of phytophagous arthropods of $R$. communis grouped by taxa with information of their host or prey and geographical distribution is shown in Table 4; as it can appreciate in this table, the most commonly reported natural enemies in countries like India, Brazil, China, and USA, are Bacillus spp., Trichogramma spp., Microplitis spp., Telenomus spp., Stethorus spp., and other species attacking pests such as $A$. janata, S. litura, Anacraga citrinopsis Dyar, 1927, S. obliqua, Phyllophaga sp., Eutetranychus banksi (McGregor, 1914), Tetranychus piercei McGregor, 1950, Zaniothrips ricini Bhatti, 1967, and other species. Table 4 shows a total of 61 
natural enemies of phytophagous insects of $R$. communis. Three species are bacteria belonging to the same genus; four species are nematodes of different genera; two species are fungi of different genera; two reports are viruses; 36 species are parasitoids of eight families of Hymenoptera and one family of Diptera; and 14 species are predators of six different families and order $74 \%$ of the species is distributed geographically in Asia, $24 \%$ in America, $2 \%$ in Africa and $0 \%$ in Europe.
An example of natural enemies of pest of $R$. communis is presented by Basappa (2009). According to this author, parasitoids, insect predators, spiders, insectivorous birds and some microbial organisms are important natural enemies of the pest complex of $R$. communis ecosystem in India. In the case of A. janata, Trichogramma chilonis Ishii, 1941, Trichogramma achaeae Nagaraja and Nagarkatti, 1970, Telenomus sp. and Trissolcus sp. were recorded from eggs; Microplitis maculipennis (Szepligeti, 1900), Euplectrus

Table 3. Order, family and geographical distribution of the pollinators and floral visitors, reported on Ricinus communis plants.

\begin{tabular}{|c|c|c|c|c|}
\hline Order & Family & Species & $\begin{array}{c}\text { Geographical } \\
\text { distribution }\end{array}$ & References \\
\hline \multirow[t]{3}{*}{ Diptera } & Muscidae & Musca domestica Linnaeus, 1758 & Cameroon & Douka and Tchuenguem (2014) \\
\hline & Richardiidae & Sepsisoma sp. & Brazil & Souza-Silva et al. (2001) \\
\hline & Syrphidae & Ischiodon scutellaris (Fabricius, 1805) & India & Navatha and Sreedevi (2012) \\
\hline \multirow[t]{2}{*}{ Hemiptera } & Coreidae & Anoplocnemis curvipes (Fabricius, 1871) & Cameroon & Douka and Tchuenguem (2014) \\
\hline & Pentatomidae & Nezara viridula Linnaeus, 1758 & India & Navatha and Sreedevi (2012) \\
\hline \multirow[t]{7}{*}{ Lepidoptera } & Nymphalidae & Acraea acerata (Hewitson, 1874) & Cameroon & Douka and Tchuenguem (2014) \\
\hline & & Acraea terpsicore (Linnaeus, 1758) & India & Navatha and Sreedevi (2012) \\
\hline & & Hypolimnas misippus (Linnaeus, 1764) & India & Navatha and Sreedevi (2012) \\
\hline & Pieridae & Catopsilia florella (Fabricius, 1775) & Cameroon & Douka and Tchuenguem (2014) \\
\hline & & Eurema blanda (Boisduval, 1836) & India & Navatha and Sreedevi (2012) \\
\hline & & Eurema sp. & Cameroon & Douka and Tchuenguem (2014) \\
\hline & & Pieris brassicae (Linnaeus, 1758) & India & Navatha and Sreedevi (2012) \\
\hline \multirow[t]{24}{*}{ Hymenoptera } & Apidae & Apis mellifera Linnaeus, 1758 & Brazil & $\begin{array}{l}\text { Freitas et al. (2009); } \\
\text { Freitas and Cruz (2010) }\end{array}$ \\
\hline & & Apis florea Fabricius, 1973 & India & Navatha and Sreedevi (2012) \\
\hline & & Ceratina sp. & India & Navatha and Sreedevi (2012) \\
\hline & & Scaptotrigona sp. & Brazil & Freitas et al. (2009) \\
\hline & & Trigona sp. & India & Navatha and Sreedevi (2012) \\
\hline & & Xylocopa fenestrata (Fabricius, 1798) & India & Navatha and Sreedevi (2012) \\
\hline & Braconidae & Bracon spp. & Mexico & Álvarez and Reyes (1987) \\
\hline & & Ephiaulax sp. & Mexico & Álvarez and Reyes (1987) \\
\hline & Chalcididae & $\begin{array}{l}\text { Conura igneoides Kirby, } 1883 \\
\text { [= Spilochalcis igneoides (Kirby, 1883)] }\end{array}$ & Mexico & Álvarez and Reyes (1987) \\
\hline & & $\begin{array}{l}\text { Conura maria } \text { Riley, } 1870 \\
\text { [= Spilochalcis mariae (Riley, 1872)] }\end{array}$ & Mexico & Álvarez and Reyes (1987) \\
\hline & Eurytomidae & Neorileya sp. & Mexico & Álvarez and Reyes (1987) \\
\hline & Formicidae & Camponotus compressus (Fabricius, 1787) & India & Navatha and Sreedevi (2012) \\
\hline & & Linepithema humile (Mayr, 1868) & USA & Line et al. (2013) \\
\hline & & Polyrachis sp. & Cameroon & Douka and Tchuenguem (2014) \\
\hline & Halictidae & Halictus sp. & India & Navatha and Sreedevi (2012) \\
\hline & Sphecidae & Liris sp. & Mexico & Álvarez and Reyes (1987) \\
\hline & & Sceliphron assimile (Dahlbom, 1843) & Mexico & Álvarez and Reyes (1987) \\
\hline & & Tachysphex sp. & Mexico & Álvarez and Reyes (1987) \\
\hline & & Tachytes sp. & Mexico & Álvarez and Reyes (1987) \\
\hline & & Trypoxilon sp. & Mexico & Álvarez and Reyes (1987) \\
\hline & Torymidae & Torymus capillaceus (Huber, 1927) & Mexico & Álvarez and Reyes (1987) \\
\hline & Vespidae & Synagris cornuta (Linnaeus, 1758) & Cameroon & Douka and Tchuenguem (2014) \\
\hline & & Delta sp. & Cameroon & Douka and Tchuenguem (2014) \\
\hline & & Polistes sp. & Mexico & Álvarez and Reyes (1987) \\
\hline
\end{tabular}


Table 4. Natural enemies of phytophagous arthropods of Ricinus communis.

\begin{tabular}{|c|c|c|c|}
\hline Species & Host and/or prey & $\begin{array}{l}\text { Geographical } \\
\text { distribution }\end{array}$ & References \\
\hline \multicolumn{4}{|c|}{ Entomopathogens } \\
\hline \multicolumn{4}{|l|}{ Bacteria } \\
\hline Bacillus thuringiensis var. kurstaki (Berliner, 1915) & Larvae of Achaea janata & India & Vimala Devi and Sudhakar (2006) \\
\hline Bacillus cereus (Manson, Pollock \& Tridgell, 1954) & Larvae of Achaea janata & India & Kattegoudar et al. (1994) \\
\hline Bacillus popilliae Dutky, 1940 & Larvae of Phyllophaga sp. & Colombia & Saldarriaga Cardona et al. (2011) \\
\hline \multicolumn{4}{|l|}{ Nematodes } \\
\hline Hexamermis dactylocercus Poinar and Linares, 1985 & Larvae of Amsacta albistriga & India & Prabhakar et al. (2010) \\
\hline Steinernema carpocapsae (Weiser, 1955) & Larvae of Spodoptera litura & India & Raveendranath et al. (2008) \\
\hline Heterorhabditis indica Poinar, Karunaka y David, 1992 & Larvae of Spodoptera litura & India & Raveendranath et al. (2008) \\
\hline Mermis sp. & Larvae of Achaea janata & India & Sujatha et al. (2011) \\
\hline \multicolumn{4}{|l|}{ Fungi } \\
\hline $\begin{array}{l}\text { Metarhizium rileyi (Farl.) Kepler, S.A.Rehner \& Humber, } 2014 \\
\text { [= Nomuraea rileyi (Farlow) Samson, 1974] }\end{array}$ & Larvae of Spodoptera litura & India and USA & Mau and Kessing (2007) \\
\hline Beauveria bassiana (Balsamo) Vuillemin, 1912 & $\begin{array}{l}\text { Larvae of Achaea janata and } \\
\text { Cogenethes punctiferalis }\end{array}$ & India & Duraimurugan et al. (2015) \\
\hline \multicolumn{4}{|l|}{ Virus } \\
\hline Nucleopolyhedrovirus & Larvae of Spodoptera litura & India & Basappa (2009) \\
\hline Granulovirus & $\begin{array}{l}\text { Larvae of Achaea janata and } \\
\text { Spodoptera litura }\end{array}$ & India & Naveen Kumar et al. (2013) \\
\hline \multicolumn{4}{|c|}{ Parasitoids } \\
\hline
\end{tabular}

\section{INSECTA}

\section{Hymenoptera}

\section{Aphelinidae}

Encarsia formosa Gahan, 1924

\section{Braconidae}

Habrobracon hebetor (Say, 1836)

Apanteles hyposidrae Wilkinson, 1928

Apanteles ricini Bhatnagar, 1948

Cotesia flavipes (Cameron, 1891)

[Apanteles flavipes (Cameron, 1891)]

Glyptapanteles dalosoma de Santis, 1987

Microplitis (= Microgaster) rufiventris Kokujev, 1914

Microplitis maculipennis (Szepligeti, 1900)

(= Microplitis ophiusae Aiyar, 1921)

\section{Chalcididae}

Brachymeria euploeae (Westwood, 1837)

\section{Eulophidae}

Ceranisus menes (Walker, 1839)

Euplectrus maternus Bhatnagar, 1952

Tetrastichus howardi (Olliff, 1893)

(= Tetrastichus ayyari Rohwer, 1921)

Trichospilus pupivorus Ferrière, 1930

\section{Trichogrammatidae}

Trichogramma achaeae Nagaraja and Nagarkatti, 1970

Trichogramma chilonis Ishii, 1941

Trichogramma minutum Riley, 1879

Trichogramma australicum Girault, 1912

Trichogramma dendrolimi Matsumura, 1926

Trichogramma pretiosum Riley, 1879

Trichogramma evanescens Westwood, 1833
Nymphs of Trialeurodes ricini

Larvae of Cogenethes punctiferalis

Larvae of Achaea janata

Larvae of Cogenethes punctiferalis

Larvae of Spilosoma obliqua and Spodoptera litura

Larvae of Anacraga citrinopsis

Larvae of Spodoptera litoralis

Larvae of Achaea janata

Pupae of Cogenethes punctiferalis

$2^{\circ}$ instar nymph of Zaniothrips ricini

Larave of Achaea janata

Pupae of Spodoptera litura and Achaea janata

Pupae of Spodoptera litura and Achaea janata

Eggs of Achaea janata

Eggs of Achaea janata and Spodoptera litura

Eggs of Achaea janata

Eggs of Achaea janata

Eggs of Achaea janata

Eggs of $S$. cosmioides

Eggs of Achaea janata
China

India

India

India

India

Brazil

Egypt

India

India

India

India

India

India

India

India

USA

China

China

Brazil

India
Wang et al. (2016)

Basappa (2003)

Basappa (2009)

Basappa (2003)

Yadav et al. (2010); Basappa (2009)

Lourenção et al. (1989)

Shalaby et al. (1988)

Suganthy (2010); Naik et al. (2010)

Sujatha et al. (2011)

Daniel et al. (1983)

Basappa (2009)

Basappa (2009)

Basappa (2009)

Basappa (2009)

Singh et al. (2008); Suganthy (2010); Naik et al. (2010)

Mau and Kessing (2007)

Hua (1984)

Hua (1984)

Cabezas et al. (2013)

Basappa (2009) 
cont...

\section{Scelionidae}

Telenomus remus Nixon, 1937

Telenomus proditor Nixon, 1937

Telenomus sp.

Trissolcus sp.

\section{Vespidae}

Polistes sp.

\section{Ichneumonidae}

Campoletis chlorideae Uchida, 1957

Charops obtusus Morley, 1913

Hyposoter exiguae (Viereck,1912)

Diadegma ricini Row \& Kurian,1950

Theronia sp.

Isdromas monterai (Costa Lima, 1948)

\section{Tachinidae}

Palexorista parachrysops Bezzi, 1925

Eucelatoria armigera (Coquillett, 1889)

Chaetogaedia monticola (Bigot, 1887)
Eggs of Spodoptera litura, Spodoptera cosmioides and Spodoptera frugiperda

Eggs of Lepidoptera

Eggs of Achaea janata

Eggs of Achaea janata

Larvae of Phyllophaga sp., Agrotis sp. and Spodoptera spp.

Larvae of Spodoptera litura

Larvae of Spilosoma obliqua and Achaea janata

Larvae of Achaea janata

Larvae of Cogenethes punctiferalis

Larvae of Cogenethes punctiferalis

Larvae of Anacraga citrinopsis

Larvae of Cogenethes punctiferalis

Larvae and pupae of Achaea janata

Larvae and pupae of Achaea janata
India

USA

India

India

Costa Rica

India

India

USA

India

India

Brazil

India

USA

USA
Satyanarayana et al. (2005); Pomari et al. (2013)

Mau and Kessing (2007)

Basappa (2009)

Basappa (2009)

Anónimo (1991)

Satyanarayana et al. (2005)

Basappa (2009)

Mau and Kessing (2007)

Basappa (2003)

Basappa (2003)

Lourenção et al. (1989)

Kalra (1984)

Mau and Kessing (2007)

Mau and Kessing (2007)

\section{Predators}

\section{Coleoptera}

\section{Carabidae}

Calosoma $\mathrm{sp}$

Larvae of Phyllophaga sp., Agrotis sp. and Spodoptera spp.

\section{Coccinellidae}

Cheilomenes sexmaculata (Fabricius, 1781)

Micraspis cardoni (Weise, 1892)

Scymnus sp.

Stethorus sp.

Stethorus siphonulus Kapur, 1948

Stethorus histrio Chazeau, 1974

\section{Hemiptera}

\section{Pentatomidae}

Eocanthecona furcellata (Wolff, 1811)

\section{Reduviidae}

Rhynocoris kumarii Ambrose and Livingstone, 1986

\author{
Eggs larvae of \\ Achaea janata and Spodoptera litura \\ Zaniothrips ricini \\ Eutetranychus orientalis \\ Eutetranychus banksi \\ Tetranychus piercei \\ Tetranychus urticae
}

Achaea janata

Eggs larvae of Achaea janata and Spodoptera litura
Costa Rica

Anónimo (1991)

Basappa (2009)

Daniel et al. (1983)

Klein (1936)

McGregor (1914)

Lui and Lui (1986)

Aguilera (1987)

India

Rao (1977); Usha Rani (2009)

India

Basappa (2009)

\section{Thysanoptera}

Aeolothripidae

Franklinothrips megalops (Trybom, 1912)

Mymarothrips garuda Ramakrishna and Margabandhu, 1931

Zaniothrips ricini

Zaniothrips ricini
India

India
Daniel et al. (1983)

Daniel et al. (1983)

\section{Neuroptera}

\section{Chrysopidae}

Chrysoperla carnea (Stephens, 1836)

Chrysoperla sp.

\author{
Tetranychus urticae \\ Eggs and larvae of \\ Achaea janata and Spodoptera litura
}

India

India

India
Rajasekhar et al. (1999)

Basappa (2009)

\section{Mantodea}

Mantidae

Haldwania lilliputana Beier, 1930

Zaniothrips ricini

ARACHNIDA / Acari

Phytoseiidae

Sciulus sp. 
maternus Bhatnagar, 1952, Rhogas spp. and Apanteles hyposidrae Wilkinson, 1928 were found among larval parasitoids; and pupae were found to be parasitised by Tetrastichus howardi (Olliff, 1893) (= Tetrastichus ayyari Rohwer, 1921) and Phorocera sp. Among insect predators of A. janata, Chrysoperla sp. and Cheilomenes sexmaculata (Fabricius, 1781) were found feeding on the eggs and neonate larvae; other general insect predators like mantids, paper wasps, and sphecid digger wasps were also found predating on larvae; spiders like green lynx spiders, jumping spiders and crab spiders were found feeding on early instar larvae. Among the entomopathogens of $A$. janata, Spodoptera litura nucleopolyhedrovirus and granulosis virus were isolated from dead larvae and the fungi Metarhizium rileyi (Farl.) Kepler, S.A.Rehner \& Humber, 2014 [= Nomuraea rileyi (Farlow) Samson, 1974] and Beauveria bassiana (Balsamo) Vuillemin were found infecting larvae (Basappa 2009). Many other examples of natural enemies of pests of $R$. communis are shown in Table 4.

\section{Pest management of phytophagous arthropods in R. communis}

Pest management methods used to control the principal arthropod pests of $R$. communis include cultural, genetic, ethological, biological, and chemical control.

Cultural control is the use of agronomical practices designed to reduce the presence of pests in crops of $R$. communis. Intercropping is a type of cultural control recommended to diminish the damage caused by insect pests in $R$. communis. Srinivasa Rao et al. (2012) found that plants such as Cyamopsis tetragonoloba (L.) Taub., 1891, Vigna unguiculata (L.) Walp., 1845, Vigna mungo (L.) Hepper, 1956, and Arachis hypogaea L., 1753, intercropped with $R$. communis in a 1:2 proportion, decreased the incidence of insect pests such as A. janata, E. flavescens, and C. punctiferalis. Moreover, a more considerable presence of natural enemies of these pests was observed in these intercropping systems. Patel and Patel (2009) recommended intercropping $R$. communis with Vigna radiata (L.) Wilczek, 1954, Sesamum indicum L., 1753, Vigna aconitifolia (Jacq.) Marechal, 1969, and $V$. unguiculata, to reduce damage by $C$. punctiferalis. When $R$. communis was monocropped, $C$. punctiferalis caused $53 \%$ damage, but when intercropped with the above mentioned species, the damage was between 35 and $53 \%$. Sowing date is another cultural method for reducing damage and the presence of pests. Salihu et al. (2014) suggest that the correct time for planting $R$. communis crop must be related to the rainy season, which is more important than any other pest control measure in Africa, since the rains decrease the presence of certain pests.

Genetic control includes the use of cultivars resistant to insect pests, however, according to Singh et al. (2015), breeding $R$. communis is complicated by limited sources of pest resistance. In India, there are $R$. communis varieties that are tolerant or resistant to attack by pests of greater economic importance, such as E. flavescens, $T$. ricini, $S$. litura, A. janata, C. punctiferalis, and L. trifolii (Anjani et al. 2010; Anjani 2012). Resistant or tolerant plants have high oil content (between 40 and $49 \%$ ) and yields that oscillate between 540 and 1,580 kg/ha (Lavanya et al. 2012). It is mentioned that the cultivars having purple leaves are resistant to the attack of $L$. trifolii, while those with green leaves are susceptible (Sarma et al. 2006; Anjani et al. 2007). Sarma et al. (2006) mention that purple-leaf varieties have high levels of anthocyanin, which make the plant more tolerant to $L$. trifolii attack, and the epicuticular wax on their leaves reduces infestation and defoliation by $A$. janata and $S$. litura. There are hybrids, such as $\mathrm{GCH} 4$, that are resistant to the attack by $E$. flavescens due to the high wax content on the plant stems and leaves (Lakshmi et al. 2005). Five accessions viz., RG-43, RG-631, RG-1621, RG-3037 and RG-3067, among 165 core set accessions representing diversity in the entire collection maintained at ICAR-Indian Institute of Oilseeds Research, Hyderabad, India, exhibited resistance reaction against $E$. flavescens; oil content of these accessions was 46, 51, 51, 51, $52 \%$, respectively (Anjani et al. 2018). On the other hand, Severino et al. (2012) recommended parallel research to determine the increased potential susceptibility to pests in breeding programs to develop low-ricin, low-ricinine, and low-allergen cultivars to reduce hazardous chemical products found in $R$. communis.

Research is being carried out on the use of transgenic plants of $R$. communis. In India, two transgenic varieties of $R$. communis, Jyothi and VP1, developed by genetic engineering induce $A$. janata mortality above $88 \%$ due to the Bacillus thuringiensis gene CryAb (Malathi et al. 2006).

A little explored method for monitoring and massive trapping of $R$. communis pests has been the use of pheromones, kairomonal attractants and light traps. In India, the pheromone compounds of some pests of economic importance have been identified and used for monitoring and massive trapping of C. punctiferalis, S. litura, Amsacta albistriga Walker, 1864 (Lepidoptera: Arctiidae), A. janata, and S. obliqua (Cork and Hall 1998). In this country, an important prerequisite for successful management of $S$. litura, the most destructive insect pest of $R$. communis damaging the crop from July- October during the south-west monsoon (kharif season), has been the implementation of an intensive monitoring program of $S$. litura population using sex pheromone traps (Satyagopal et al. 2014). Setting twelve traps baited with pheromone compounds per hectare for massive trapping of $S$. litura is recommended (Nandagopal and Rathod 2007; Raghavaiah 2011). In Brazil, researchers are now taking the first steps toward identifying the pheromone compounds of $C$. gossypii (Fregadolli et al. 2012) with the aim of developing a commercial pheromone. In India, the kairomonal compounds of the most destructive lepidopteran insect pest of $R$. communis, such as $S$. litura, $A$. janata, and $C$. punctiferalis have been identified for trapping. In field experiment, water trap baited with phenyl acetaldehyde + 2-phenyl ethanol recorded significantly higher moth catches of $S$. litura $(6.8$ moths/trap/wk) and $C$. punctiferalis (5.8 moths/trap/wk) (Duraimurugan et al. 2017). Recently, Duraimurugan and Alivelu (2018), determined the relationship of pheromone trap catches corresponding to the economic threshold level of $25 \%$ defoliation of $S$. litura on $R$. communis, which was estimated to be $81.4 \mathrm{moths} / \mathrm{trap} / \mathrm{week}$. Light traps using ultraviolet black-blue spectrum have also been suggested to capture Phyllophaga sp. adults as a measure of ethological control Saldarriaga Cardona et al. (2011).

Biological control (spraying entomopathogenic microorganisms and releasing entomophagous insects) has been implemented in the control of key $R$. communis pests in countries such as India and Colombia. In India, for example, parasitism rates between 10.4 and $28.7 \%$ of $M$. maculipennis and Cotesia sp. were recorded on larvae of $A$. janata and $S$. 
litura, respectively (Suganthy 2007), while $9.5 \%$ parasitism rates of Cotesia flavipes (Cameron, 1891) against S. obliqua larvae have been observed (Yadav et al. 2010). Also, in India, Rajasekhar et al. (1999) mention that when Chrysoperla carnea (Stephens, 1836) were released, the T. urticae $(=T$. telarius) mite populations diminished by $75 \%$. In the case of S. litura, the release of 150 adults of the parasitoid Telenomus remus (Nixon, 1937) per egg mass and the release of the larval parasitoid Campoletis chlorideae Uchida, 1957 in a parasitoid: host ratio of 1:15 achieved parasitism rates above $96 \%$ (Satyanarayana et al. 2005).

Biological control through entomopathogenic nematodes, bacteria, fungi, and virus exposed to the principal pests of $R$. communis has been evaluated in India. For instance, mortality of $S$. litura pupae was evaluated with two nematode species: Heterorhabditis indica Poinar, Karunaka and David, 1992, and Steinernema carpocapsae (Weiser, 1955) (Raveendranath et al. 2008). Other studies evaluated the mortality of $A$. janata and Samia ricini (Drury, 1773) larvae exposed to two species of bacteria: Bacillus thuringiensis Berliner, 1915 and Bacillus cereus Frankland \& Frankland 1887 (Manson et al. 1954; Kattegoudar et al. 1994; Mathur et al. 1994; Vimala Devi and Sudhakar 2006). Duraimurugan et al. (2015) conducted research to determine the mortality of $A$. janata larvae and C. punctiferalis adults with Beauveria bassiana (Balsamo) Vuillemin, 1912 fungus. Mortality of $A$. janata larvae exposed to granulovirus was also evaluated (Naveen Kumar et al. 2013). In Colombia, Saldarriaga Cardona et al. (2011) reported that the control of Phyllophaga sp. larvae was achieved by applying the $B$. popilliae Dutky bacterium at a concentration of $24,000.00$ billion spores/ha a year, during five consecutive years.

The use of secondary metabolites derived from plants and other organisms, as well as methods of chemical control, have been assessed for controlling some $R$. communis pests. In laboratory studies, it has been found that methanol extracts of Clathria longitoxa (Hentschel, 1912) and Callyspongia diffusa (Ridley, 1884), two marine sponges, have insecticidal effect on A. janata and P. recini larvae (Joseph et al. 2010). Furthermore, Calotropis gigantea (L.) W. T. Aiton, 1811, leaf extracts demonstrated strong feeding deterrent activity against larvae of Pericallia ricini (Fabricius, 1775) at high concentrations (Neelanarayanan and Indira 2010). Likewise, toxic effects and strong antifeedant activity of raw acetonic extracts of Mormodica charantia L., 1753, Tectona grandis L. f., 1790, and Madhuca indica J. F. Gmel., (1791) against $S$. litura and A. janata larvae (Devanand and Usha Rani 2008) were found. Neem, Azadirachta indica (Juss, 1830), also evaluated for the control of S. litura, induces mortality of larvae at high concentrations (Choudhury and Aizur Rahman 2008).

Chemical control through insecticides is one of the most common practices for control of $R$. communis pests (Gahukar 2018). In Colombia, six pesticides for the control of C. gossypii were evaluated. The results of insect control efficacy three days after pesticide application were as follows: (from the least to the most effective) thiamethoxam + lambda-cihalotrin $(0.00$ $\%)$, spinetoram $(0.00 \%)$, malathion $(20.35 \%)$, thiamethoxam (38.62\%), dimethoate (86.94\%), and imidacloprid $(87.33 \%)$; whereas after seven days the following results were obtained: thiamethoxam + lambda-cihalotrin $(0.00 \%)$, spinetoram $(21.46 \%)$, malathion $(38.77 \%)$, thiamethoxam (50.84\%), dimethoate $(86.14 \%)$, and imidacloprid $(90.37 \%$ ) (Varón et al. 2010). Mead (1989) suggested the use of carbaryl or malathion for controlling C. gossypii in Florida, USA. In Colombia, Saldarriaga Cardona et al. (2011) recommended application of baits poisoned with carbaryl at a dose of 2 to $3 \mathrm{~g} / \mathrm{L}$ for the control of $A$. ipsilon and $S$. frugiperda; the same authors recommended application of liquid chlorpyrifos at the base of the plants at a dose of $1.5-2.0 \mathrm{cc} / \mathrm{L}$.

The most recommendable strategy of $R$. communis pest control is Integrated Pest Management (IPM). Most of the IPM programs have been directed against key pests of $R$. communis, such as $S$. litura, $C$. punctiferalis, and $A$. janata (Prabhakar et al. 2003; Singh et al. 2006; Basappa 2009). In India, the growers increased seed production of $R$. communis up to $28 \%$, by implementing IPM programs with insecticides, crop rotation, insect traps, application of neem extract, and intercropping (Basappa 2007). The results of research in India demonstrate that IPM is an efficient strategy for the control of $A$. janata and $S$. litura, two of the key pests of $R$. communis. It is possible to decrease populations of these pests by using the recommended IPM program, which includes the use of bird perches for predatory birds to rest and to look for preys, foliar applications of $5 \%$ neem seed extracts, biological insecticide consisting of nuclear polyhedrosis virus (S. litura NPV 100 LE/ha), monocrotophos at $0.5 \%$, and manual removal of larvae (Suganthy 2010). The pest control effectiveness of carbaryl 50W $0.2 \%$, endosulfan $35 \mathrm{EC} 0.05 \%$, triazophos 40 EC $0.05 \%$, spinosad 45 SC $0.018 \%$, fipronil SSC $0.01 \%$, extract of neem seeds $5 \%$ (weight/volume), B. thuringiensis $0.1 \%$, and a control without applying the dose of $500 \mathrm{~L} / \mathrm{ha}$, was evaluated under field conditions 30 and 45 days after establishing a plantation of a $R$. communis variety susceptible to leafminer $L$. trifolii. The results showed that the least damage (lowest number of insect mines) was found when spinosad and triazophos were applied and, at the same time, the best yield was obtained with both treatments ( 883 and 835 $\mathrm{kg} \mathrm{seed} /$ ha, respectively) (Akashe et al. 2009). On the other hand, natural enemy impact has been proven to be greatest at sites adopting biointensive IPM (BIPM); par example, studies conducted by Basappa (2009) shown that BIPM modules were safer to A. janata eggs (T. chilonis) and larvae (M. maculipennis) parasitoids with 16.1 and $66.1 \%$ average field parasitism, compared to chemical pesticide intensive integrated pest management modules with 6.9 and $21.2 \%$ parasitism, respectively.

\section{Conclusions}

There is a wide range of arthropods that damage $R$. communis in different parts of the world where this plant is cultivated; many of these are considered pests of economic importance. Likewise, there are reports of a great variety of natural enemies, which have been used in biological control programs. According to the coevolutive hypothesis, it was found that the greatest richness and abundance of arthropods associated with $R$. communis is in Asia and Africa, considered as the center of origin of this plant. Most phytophagous arthropods feed on leaves. The natural enemies with more abundance and richness are the parasitoids that mostly attack the larvae of phytophagous arthropods. With respect to pollinators, A. mellifera is the principal pollinating insect, however, more research on pollination and floral ecology in $R$. communis is needed, in order to determine what other floral visitors may act as pollinators, and how they can be protected or manipulated to increase crop yield. The pest management 
programs of phytophagous arthropods of $R$. communis must be directed toward promoting and preserving natural enemies and pollinating insects by means of environment-friendly pest management techniques, for which use of wide-spectrum insecticides must be avoided.

\section{Acknowledgements}

We are grateful to Fernando E. Vega [Insect Biocontrol Laboratory, US Department of Agriculture, Agricultural Research Service (USDA-ARS), Beltsville, MD] for suggestions leading to improvement the first version of the manuscript.

\section{Literature cited}

ABDULLAH, N. M. M.; MARTIN, J. 2007. New record for four additional whiteflies species from Yemen. Arab Journal of Plant Protection 25: 33-34.

AGUILERA, P. A. 1987. New localities for Stethorus histrio Chazeau (Coleoptera Coccinellidae) in Chile. Revista Chilena de Entomología 15: 33-36.

AHUJA, D. B. 1994. Seasonal incidence and chemical control of oriental mite, Eutetranychus orientalis (Klein) on castor. Indian Journal of Entomology 56: 1-5.

AKASHE, V. B.; GUD, M. A.; SHINDE, S. K.; DESHPANDE, A. N. 2009. Bio-efficacy of botanicals and chemical insecticides for control of leaf miner (Liriomyza trifolii Burges) under dry land condition. An Asian Journal of Soil Science 4: 315-317.

ALI, M. S.; KUMAR, K.; SINGH, R. 2006. Host range of Oxyrhachis tarandus Fabricus (Homoptera: Membracidae) in woody trees and shrubs of Bihar. Environment and Ecology (Kalyani) 24S: 14-16.

ÁlVAREZ, P. C.; REYES, F. 1987. Himenópteros entomófagos adultos que se alimentan en los nectarios de algunas malezas comunes en Nuevo León, México. The Southwestern Entomologist 12: 205-2010.

AMOABENG, B. W.; GURR, G. M.; GITAU, C. W.; STEVENSON, P. C. 2014. Cost: benefit analysis of botanical insecticide use in cabbage: Implications for smallholder farmers in developing countries. Crop Protection 57: 71-76. https://doi.org/10.1016/j. cropro.2013.11.019

ANJANI, K. 2012. Castor genetic resources: A primary gene pool for exploitation. Industrial Crops and Products 35 (1): 1-14. https://doi.org/10.1016/j.indcrop.2011.06.011

ANJANI, K.; PALLAVI, M.; SUDHAKARA BABU, S. N. 2007. Uniparental inheritance of purple leaf and the associated resistance to leafminer in castor bean. Plant Breeding 126 (5): 515-520. https://doi.org/10.1111/j.1439-0523.2007.01395.x

ANJANI, K.; PALLAVI, M.; SUDHAKARA BABU, S. N. 2010. Biochemical basis of resistance to leafminer in castor (Ricinus communis L.). Industrial Crops and Products 31 (1): 192-196. https://doi.org/10.1016/j.indcrop.2009.10.005

ANJANI, K.; RAOOF, M. A.; LAKSHMI PRASAD, M. S.; DURAIMURUGAN, P.; LUCOSE, C.; YADAV, P.; PRASAD, R. D.; JAWAHAR LAL, J.; SARADA, C. 2018. Trait-specific accessions in global castor (Ricinus communis L.) germplasm core set for utilization in castor improvement. Industrial Crops and Products 112: 766-774. https://doi.org/10.1016/j. indcrop.2018.01.002

ANÓNIMO. 1991. Dirección General de Investigación y Extensión Agrícola. Ministerio de Agricultura y Ganadería. San José, Costa Rica. $571 \mathrm{p}$.

ANONYMOUS. 1913. Insects injurious to papaw apples in Queensland. Queensland Agricultural Journal 27: 33-35.

ARKHANGEL'SKII, N. N.; ROMANOVA, V. P. 1930. Pests of sunflower and castor in the north Caucasian Region. Bulletin of the North Caucasian Plant Protection Station vi-vii: 199-216.
AUDI, J.; BELSON, M.; PATEL, M.; SCHIER, J.; OSTERLOH, J. 2005. Ricin poisoning. A comprehensive review. Journal of the American Medical Association 294 (18): 2342-2351. https://doi. org/10.1001/jama.294.18.2342

BALDWIN, B. S.; COSSAR, R. D. 2009. Castor yield in response to planting date at four locations in the south-central United States. Industrial Crops and Products 29 (2-3): 316-319. https://doi. org/10.1016/j.indcrop.2008.06.004

BARNES, D. J.; BALDWIN, B. S.; BRAASCH, D. A. 2009. Degradation of ricin in castor seed meal by temperature and chemical treatment. Industrial Crops and Products 29 (2-3): 509515. https://doi.org/10.1016/j.indcrop.2008.09.006

BARTENEVA, R. V. 1986. Diseases and pests of castor and their control. pp. 101-101. In: Moshkin, V. A. (Ed.). Castor. Oxonian Press Pvt Ltd. New Delhi. 284 p.

BASAPPA, H. 2003. Integrated pest management in Castor. Hyderabad: Directorate of Oilseeds Research (ICAR), India, $52 \mathrm{p}$.

BASAPPA, H. 2007. Validation of integrated pest management modules for castor (Ricinus communis) in Andra Pradesh. The Indian Journal of Agricultural Sciences 77: 357-362.

BASAPPA, H. 2009. Impact of integrated pest management modules on the activity of natural enemies in castor ecosystem. Journal of Biological Control 23: 221-228.

BASAPPA, H.; LINGAPPA, S. 2001. Damage potential of Achaea janata Linn at different phenological stages of castor. Indian Journal of Plant Protection 29: 17-24.

BAVARESCO, A.; SILVEIRA GARCIA, M.; DIONEI GRÜTZMACHER, A.; FORESTI, J.; RINGENBERG, R. 2003. Compared biology of Spodoptera cosmioides (Walk.) (Lepidoptera: Noctuidae) in onion, castor oil plant, soybean and bean. Ciência Rural, Santa Maria 33 (6): 993-998. https://doi. org/10.1590/S0103-84782003000600001

BIGI, M. F.; TORKOMIAN, V. L. V.; DE GROOTE, S. T. C. S.; HEBling, M. J. A.; BUENO, O. C.; PAGNOCCA, F. C.; FERNANDES, J. B.; VIEIRA, P. C.; SILVA, M. F. 2004. Activity of Ricinus communis (Euphorbiaceae) and ricinine against the leaf-cutting ant Atta sexdens rubropilosa (Hymenoptera: Formicidae) and the symbiotic fungus Leucoagaricus gongylophorus. Pest Management Science 60 (9): 933-938. https://doi.org/10.1002/ps.892

BIRCHLER, J. A.; AUGER, D. L.; RIDDLE, N. C. 2003. In search of the molecular basis of heterosis. The Plant Cell 15: 22362239. https://doi.org/10.1105/tpc. 151030

BOLAND, J. M. 2016. The impact of an invasive ambrosia beetle on the riparian habitats of the Tijuana River Valley, California. PeerJ 4: e2141. https://doi.org/10.7717/peerj.2141

BOURNE-MURRIETA, L. R.; WONG-CORRAL, F. J.; BORBOAFLORES, J.; CINCO-MOROYOQUI, F. J. 2014. Daños causados por el barrenador mayor de los granos Prostephanus truncatus (Horn) (Coleoptera: Bostrichidae) en maíz y ramas de plantas silvestres. Revista Chapingo. Serie ciencias forestales y del ambiente 20 (1): 63-75. http://www.scielo.org.mx/scielo. php?script $=$ sci_arttext\&pid=S2007-40182014000100007

CABEZAS, G. F.; MELO, M.; GARCÍA, M. S.; DIEZRODRÍGUEZ, G. I.; NAVA, D. E. 2013. Parasitismo de Trichogramma pretiosum (Hymenoptera: Trichogrammatidae) sobre Spodoptera cosmioides (Lepidoptera: Noctuidae) a diferentes temperaturas. Revista Colombiana de Entomología 39: 216-220.

CANGARDEL, H. 1954. Experiments on the control of the castor bean red spider. Essais de lutte centre l'araignee rouge du ricin. Terre Mame 28: 53-55.

CAVAlCANTE, R. D.; PEDROSA, F. N. T.; DE ARAUJO, F. E. 1974. Pantomorus glaucus (Perty, 1830), a pest of various crops in the State of Ceara. Fitossanidade 1: 22.

CÉSAR, A. da S.; BATALHA, M. O. 2010. Biodiesel production from castor oil in Brazil: A difficult reality. Energy Policy 38 (8): 4031-4039. https://doi.org/10.1016/j.enpol.2010.03.027 
CHOUDHURY, P.; AIZUR RAHMAN, S. M. 2008. Neem effects of growth and development of Spodoptera litura Fab. Progressive Reseach 3: 2011-2012.

CORK, A.; HALL, D. R. 1998. Application of pheromones for crop pest management in the Indian Sub-continent. Journal of Asia-Pacific Entomology 1 (1): 35-49. https://doi.org/10.1016/ S1226-8615(08)60005-9

DANIEL, A. M.; KUMAR, N. S.; BAKTHAVATSALAM, N. 1983. Bioecology of Zaniothrips ricini Bhati (Panchaetothripinae: Terebrantia: Thysanoptera) - A new thrips pest of castor (Ricinus communis: Euphorbiaceae). Proceedings: Animal Sciences 92 (2): 87-94. https://doi.org/10.1007/BF03186174

DARLING, H. S. 1946. Annual Report of the Agricultural Entomologist. Report. Department of Agriculture, Uganda, pt. 2, pp. 25-30.

DE ONG, E. R. 1918. Insect pests of the castor bean. Journal of Economic Entomology 11 (6): 480. https://doi.org/10.1093/ jee/11.6.480

DE SIBIO, P. R.; ROSSI, M. N. 2016. Interaction effect between herbivory and plant fertilization on extrafloral nectar production and on seed traits: An experimental study with Ricinus communis (Euphorbiaceae). Journal of Economic Entomology 109 (4): 1612-1618. https://doi.org/10.1093/jee/tow115

DELAYA, V. P.; RAJPUT, S. G.; AWATE, B. G.; MOHITE, P. B. 1985. Chemical control of castor semilooper Achoea janata Linnaeus. Indian Journal of Plant Protection 11: 136-137.

DEVANAND, P.; USHA RANI, P. 2008. Biological potency of certain plant extracts in management of two lepidopteran pests of Ricinus communis L. Journal of Biopesticides 1: 170-176.

DINESH, D. S.; KUMARI, S.; KUMAR, V.; DAS, P. 2014. The potentiality of botanicals and their products as an alternative to chemical insecticides to sandflies (Diptera: Psychodidae): A review. Journal of Vector Borne Diseases 51: 1-7.

DOUKA, C.; TCHUENGUEM, F. N. 2014. Foraging and pollination activity of Musca domestica L. (Diptera: Muscidae) on flowers of Ricinus communis L. (Euphorbiaceae) at Maroua, Cameroon. Journal of Biodiversity and Environmental Sciences 4: 63-76.

DURAIMURUGAN, P.; ALIVELU, K. 2018. Determination of an action threshold for tobacco caterpillar, Spodoptera litura (F.) based on pheromone trap catches in castor (Ricinus communis L.). Journal of Entomological Research 42 (2): 189-194. https:// doi.org/10.5958/0974-4576.2018.00032.4

DURAIMURUGAN, P.; LAKSHMINARAYANA, M.; VIMALA DEVI, P. S. 2015. Comparative efficacy of microbial, botanical and chemical insecticides against lepidopteran pests in castor. The Ecoscan 9: 7-10.

DURAIMURUGAN, P.; SAMPATHKUMAR, M.; SRINIVAS, P. S. 2017. Field evaluation of synthetic kairomonal attractants against major lepidopteran pests of castor. Journal of Environmental Biology 38: 1421-1427. https://doi.org/10.22438/jeb/38/6/ MRN-629

DURÁN, J. M.; PARRA, N. R.; YUGUEROS, R. M.; DE PAULA QUEIROGA, V. 2010. El cultivo de ricino (Ricinus communis L.) en Andalucía: Una alternativa para producción de biodiésel. pp. 39-58. En: Recalde, E. R.; Durán Altisent Posso, J. M. (Eds.). Cultivos Energéticos Alternativos. Centro Iberoamericano de Investigación y Transferencia de Tecnología en Oleaginosas (CIITOL), Grupo Seritex, Ecuador. 177 p.

EGONYU, J. P.; MUKASA, Y.; EKWARU, R.; OGARI, I.; AHUMUZA, G. 2017. Occurrence of Euwallacea sp. (Coleoptera: Scolytidae) and its ambrosia fungus Cunninghamella echinulata on Ricinus communis in Coffea canephora gardens in Uganda. International Journal of Tropical Insect Science 37 (3): 198-207. https://doi.org/10.1017/S1742758417000121

EL-SHAARAWY, M. F.; GOMAA, A. A.; EL-GARHY, A. T. 1975. Chemical determination and utilization of dietary constituents of two-castor bean varieties by larvae of the Eri silk worm, Attacus ricini Boisd. Zeitschrift für Angewandte Entomologie 78 (1-4): 171-176. https://doi.org/10.1111/j.1439-0418.1975.tb04166.x
FAOSTAT, Food and Agriculture Organization of the United Nations. 2015. Production-castor oil sedes. In: http://faostat.fao. org/site/567/DesktopDefault.aspx?PageID=567. [Review date: 19 February 2017].

FREGADOLLI, A. M. V.; FREGADOLLI, F. L.; OLIVEIRA, M. S. DE; SILVA, M. J. C. DA; FERREIRA, P. V.; ENDRES, L.; SILVA, R. M.; MACUVELE, D. L. P.; GOULART, H. F.; SANT'ANA, A. E. G.; PIRES, E. V. 2012. Busca da composição feromonal de Corythucha gossypii, Cyclocephala melanocephala e Pachycoris torridus. EnerBiomassa'12, Maceió, Alagoas, Brasil, 21 a 23 de Novembro 2012 / Brazil, 21-23 November, 2012. A2.4 (EB 065). 2 p.

FREITAS, B. M.; CRUZ, D. de O. 2010. As abelhas na polinização de culturas agrícolas. pp. 9-21. In: Cohelo de Lima, M. A. (Ed.). II Semana dos Polinizadores: Palestras, 28 e 29 de setembro de 2009, Petrolina, PE, EMBRAPA, Brasil. 82 p.

FREITAS, B. M.; RIZZARDO, R.A.G.; MILFONT, M. de O. 2009. Pollination and honney production in castor bean (Ricinus communis L.) plantations for biofuel. $41^{\mathrm{a}}$ Apimondia Congress September 2009, Montpellier, France. 29 p.

GAHUKAR, R. T. 2010. Bioefficacy of indigenous plant products against pests and diseases of Indian forest trees: A review. Journal of Forestry Research 21: 231-238. https://doi.org/10.1007/ s11676-010-0038-7

GAHUKAR, R. T. 2018. Management of pests and diseases of castor (Ricinus communis L.) in India: current status and future perspective. Archives of Phytopathology and Plant Protection 51 (17-18): 956-978. https://doi.org/10.1080/03235408.2018.1541 655

GALANDE, S. M.; MOTE, U. N.; GHORPADE, S. A. 2005. Host range of serpentine leafminer (Liriomyza trifolii Burgess) and its activity in scarcity zone. Journal of Maharashtra Agricultural Universities 30: 307-310.

GEETHA, B.; VENKATESAN, S.; SHANMUGAM, K. 2003. Occurrence of Helicoverpa armigera (Hubner) on castor capsules in Tamil Nadu. Insect Environment 9: 170-171.

GHOSH, C. C. 1914. Life-Histories of Indian Insects. Lepidoptera. Memoirs of the Department of Agriculture 5: 1-72.

GOLDEN, M.; FOLLETT, P. A. 2006. First report of Nezara viridula f. aurantiaca (Hemiptera: Pentatomidae) in Hawaii. Proceedings of the Hawaiian Entomological Society 38: 131-132.

GOVAERTS, R.; FRODIN, D. G.; RADCLIFFE-SMITH, A. 2000. World checklist and bibliography of Euphorbiaceae (with Pandaceae). Redwood Books Limited, Trowbridge, Wiltshire. $1621 \mathrm{p}$.

HEDGE, J. N.; CHAKRAVARTHY, A. K.; GANIGAR, P. C. 2009. Screening castor (Ricinus communis Linn.) germplasm against leafminer, Liriomyza trifolii, semilooper, Achaea janata and shoot and capsule borer, Conogethes punctiferalis in South Karnataka. Current Biotica 3: 386-396.

HEIL, M. 2008. Indirect defence via tritrophic interactions. New Phytologist 178 (1): 41-61. https://doi.org/10.1111/j.14698137.2007.02330.x

HEUNGENS, A.; DEGHEELE, D. 1986. Control of the broad mite, Polyphagotarsonemus latus (Banks), with acaricides on Psophocarpus tetragonolobus and Ricinus communis. Parasitica 42: 3-10.

HUA, Y. Q. 1984. Occurrence and control of Achaea melicerta (Drury). Insect Knowledge (Kunchong Zhishi) 18: 171-172. https://doi.org/10.1002/j.1545-7249.1984.tb00512.x

HUERTAS DIONISIO, M. 2002. Lepidópteros de Huelva (I) especies detectadas en las márgenes del Río Guadiana. Boletín de la SAE, No. 4: 9-29.

HUSSAIN, M.; KHAN, M. Q. 1966. Record of Lasioderma serricorne F. (Anobiidae: Coleoptera) on stored castor beans. Science and Culture 32: 212.

IDRISS, M.; ABDALLAH, N.; AREF, N.; HARIDY, G.; MADKOUR, M. 1997. Biotypes of the castor bean whitefly Trialeurodes ricini (Misra) (Hom. Aleyrodidae) in Egypt: 
biochemical characterization and efficiency of geminivirus transmission. Journal of Applied Entomology 121 (1-5): 501509. https://doi.org/10.1111/j.1439-0418.1997.tb01440.x

ISLAM, W.; NARGIS, A.; JOARDER, O. I. 1988. Biology, seasonal occurrence, host range and damage potential of the castor hairy caterpillar, Euproctis lunata Walk. (Lymentriidae: Lepidoptera). Crop Protection 7 (5): 332-335. https://doi.org/10.1016/02612194(88)90081-6

JACOB, P. S.; RAMASUBBARAO, V.; PUNNAIAH, K. C. 2000. Leafhopper fauna associated with oilseed crops in Andhra Pradesh, India. Pest Management and Economic Zoology 8: 1127.

JANNONE, G. 1952. Studies and researches on agricultural entomology in Eritrea and Ethiopia. VIII. The phytopathological condition of crops on a farm in the Fadis territory (Harar, Ethiopia) with particular reference to an infestation of Aphids on safflower. Rivista di Agricoltura Subtropicale e Tropicale 46: 132-137.

JAYARAJ, S. 1964. Influence of a phytotoxemia on the activities of catalase and free auxins of castor bean varieties in relation to their resistance to Empoasca flavescens (F.) (Homoptera, Jassidae). Zeitschrift für Angewandte Entomologie 63 (1-4): 3239. https://doi.org/10.1111/j.1439-0418.1969.tb04360.x

JENA, J.; GUPTA, A. K. 2012. Ricinus communis Linn: A phytopharmacological review. International Journal of Pharmacy and Pharmaceutical Sciences 4: 25-29.

JOSEPH, B.; SUJATHA, S.; JEEVITHA, M. V. 2010. Screening of pesticidal activities of some marine sponge extracts against chosen pests. Journal of Biopesticides 3: 495-498.

JUNIOR, E. M. de A.; FERNANDES, I. M. dos S.; SANTOS, C. S.; MESQUITA, L. X.; PEREIRA, R. A.; BORGES MARACAJÁ, P. B.; SOTO-BLANCO, B. 2011. Toxicity of castor bean (Ricinus communis) pollen to honeybees. Agriculture, Ecosystems and Environment 141 (1-2): 221-223. https://doi.org/10.1016/j. agee.2011.02.010

JYOTHSNA, Y.; KAPIL, M.; USHA, R. 2009. Effects of herbivore feeding on biochemical and nutrient profile of castor bean, Ricinus communis L. plants. Allelopathy Journal 24: 131-132.

KALRA, V. K. 1984. Palexorista parachrysops parasitizing castor capsule borer. Plant Protection Bulletin, FAO 32: 30.

KATTEGOUDAR, N. F.; ALAGAWADI, A. R.; PAKALE, N. 1994. Efficacy of whole culture of Bacillus cereus and culture filtrate against the castor semilooper, Achaea janata L. Journal of Entomological Research (New Delhi) 18: 223-227.

KHATTAK, S. U.; JABBAR, A.; HUSSAIN, N. 1991. Studies on host plants of hairy caterpillar Diacrisia obliqua Wlk in Peshawar. Pakistan Journal of Zoology 23: 297-300.

KIRKMAN, W.; MOORE, S. 2007. A study of alternative hosts for the false codling moth, Thaumatotibia (=Cryptophlebia) leucotreta in the Eastern Cape. South African Fruit Journal 6: 33-38.

KITTOCK, D. L.; WILLIAMS, J. H. 1970. Effects of plant population on castorbean yield. Agronomy Journal 62 (4): 527-529. https:// doi.org/10.2134/agronj1970.00021962006200040030x

KLEIN, H. Z. 1936. Contributions to the knowledge of the red spiders in Palestine. I. The oriental red spider, Anychus orientalis Zacher. Bulletin Agricultural Experimental Station, Rehovoth 21: 2-36.

KOLTE, S. J. 1995. Castor diseases and crop improvement. Shipra publications, Delhi, India. $119 \mathrm{p}$.

LAKSHMAMMA, P.; LAKSHMINARAYANA, M.; LAKSHMI, P.; ALIVELU, K.; LAVANYA, C. 2009. Effect of defoliation on seed yield of castor (Ricinus communis). The Indian Journal of Agricultural Sciences 79: 620-623.

LAKSHMI, P.; LAKSHMAMMA，P.; LAKSHMINARAYANA, M. 2010. Contribution of upper leaves to seed yield of castor. Journal of Oilseeds Research 27: 209-212.

LAKSHMI, P. V.; SATYANARAYANA, J.; SINGH, H.; RATNASUDHAKAR, T. 2005. Incidence of green leafhopper,
Empoasca flavescens Fab., on castor, Ricinus communis L., in relation to morphological characters and date of sowing. Journal of Oilseeds Research 22: 93-99.

LAMA, A. D.; VUORISALO, T.; NIEMELÄ, P. 2015. Global patterns of arthropod herbivory on an invasive plant, the physic nut (Jatropha curcas L.). Journal of Applied Entomology 139 (1-2): 1-10. https://doi.org/10.1111/jen.12161

LAVANYA, C.; MURTHY, I. Y. L. N.; NAGARAJ, G.; MUKTA, N. 2012. Prospects of castor (Ricinus communis L.) genotypes for biodiesel production in India. Biomass and Bioenergy 39: 204209. https://doi.org/10.1016/j.biombioe.2012.01.008

LIMA, R. L. S.; SEVERINO, L. S.; SAMPAIO, L. R.; SOFIATTI, V.; GOMES, J. A.; BELTRÃO, N. E. M. 2011. Blends of castor meal and castor husks for optimized use as organic fertilizer. Industrial Crops and Products 33 (2): 364-368. https://doi. org/10.1016/j.indcrop.2010.11.008

LINE, S.; HONG, K.; CARMONA-GALINDO, V. D. 2013. The relationship between castor bean stem diameter and extrafloral nectary gland size. Bios 84 (2): 98-100. https://doi. org/10.1893/0005-3155-84.2.98

LIU, X; LI, D. 2006. Biological activity of ricinine and outlook of its applied development. Chinese Journal of Pharmacology and Toxicology 20 (1): 76-78.

LOHAR, M. K.; JUNO, G. M.; LANJAR, A. G.; RAHOO, G. M.; MAHAR, A. N. 1997. Seasonal population and host plants of Spodoptera litura (F.) in lower Sindh. Pakistan Entomologist 19: 53-57.

LONDOÑO-ZULUAGA, M. 2008. Plagas. pp. 15-17. In: Navas, A. A.; Córdoba, O.; Bran, A.; Macias, F. (Eds.). Higuerilla: Alternativa Productiva, Energética y Agroindustrial para Colombia. Corpoica, Rionegro, Antioquia, Colombia. 34 p.

LÓPEZ-GUILLÉN, G.; GÓMEZ RUIZ, J.; BARRERAGAYTÁN, J. F.; HERNÁNDEZ-GÓMEZ, E.; ZAMARRIPACOLMENERO, A. 2012. Artrópodos asociados a Jatropha curcas L. y Ricinus communis L. en Chiapas. Entomología Mexicana 11: 375-380.

LOURENÇÃO, A. L.; DE CARVALHO, L. O.; DE CAMPOS LASCA, E. D. H. 1989. Anacraga citrinopsis Dyar (Lepidoptera: Dalceridae) em mamoneira no estado de São Paulo. Bragantia Campinas 48 (1): 109-112. https://doi.org/10.1590/S000687051989000100010

LU, Y.; WU, K.; WYCKHUYS, K. A. G.; GUO, Y. 2010. Overwintering hosts of Apolygus lucorum (Hemiptera: Miridae) in northern China. Crop Protection 29 (9): 1026-1033. https:// doi.org/10.1016/j.cropro.2010.03.017

LUI, Z. G.; LUI, N. Z. 1986. A preliminary report on Tetranychus piercei McGregor. Insect Knowledge 23:18-19.

MALATHI, B.; RAMESH, S.; RAO, K. V.; REDDY, V. D. 2006. Agrobacterium-mediated genetic transformation and production of semilooper resistant transgenic castor (Ricinus communis L.). Euphytica 147: 441-449. https://doi.org/10.1007/s10681-0059043-x

MANSON, E. E. D.; POLLOCK, M. R.; TRIDGELL, E. J. 1954. A comparison of the properties of penicillinase produced by Bacillus subtilis and Bacillus cereus with and without addition of penicillin. Journal of General Microbiology 11 (3): 493-505. https://doi.org/10.1099/00221287-11-3-493

MARTÍN, C.; MOURE, A.; MARTÍN, G.; CARRILLO, E.; DOMÍNGUEZ, H.; PARAJÓ, J. C. 2010. Fractional characterisation of jatropha, neem, moringa, trisperma, castor and candlenut seeds as potential feedstocks for biodiesel production in Cuba. Biomass and Bioenergy 34 (4): 533-538. https://doi.org/10.1016/j.biombioe.2009.12.019

MARTÍNEZ, M. A.; BLANCO, E.; SURÍS, M. 2005. Fauna de chinches harinosas (Hemiptera: Coccoidea) asociada a plantas de interés: I. plantas arbóreas. Revista de Protección Vegetal 20: 125-127.

MATHUR, Y. K.; ALAM, M. A.; KUMAR, J. 1994. Effectiveness of different formulations of Bacillus thuringiensis Berliner against 
Pericallia ricini Fabricius (Lepidoptera: Arctiidae). Journal of Entomological Research (New Delhi) 18: 95-104.

MAU, R. F. L.; KESSING, J. L. M. 2007. Achaea janata (Linnaeus). Available in: http: $\backslash$ Achaea janata.mht [Review date: 05 October 2015].

McGREGOR, E. A. 1914. Four new tetranychids. Annals of the Entomological Society of America 7 (4): 354-364. https://doi. org/10.1093/aesa/7.4.354

McQUATE, G. T.; JAMESON, M. L. 2011. Control of Chinese rose beetle through the use of solar-powered nighttime illumination. Entomologia Experimentalis et Applicata 141 (3): 187-96. https://doi.org/10.1111/j.1570-7458.2011.01186.x

MEAD, F. W. 1989. Cotton lace bug, Corythucha gossypii in Florida (Hemiptera: Tingidae). Fla. Dept. Agr. \& Consumer Serv. Divison of Plant Industry. Entomology Circular No. 324: 4.

MILLER, L. T.; NAGAMINE, W. T. 2005. First records of Corythucha gossypii (Hemiptera: Tingidae) in Hawaii, including notes on host plants. Proceedings of the Hawaiian Entomological Society 37: 85-88.

MOLL, R. H.; SALHUANA, W. S.; ROBINSON, H. F. 1962. Heterosis and genetic diversity in variety crosses of maize. Crop Science 2 (3): 197-198. https://doi.org/10.2135/cropsci1962.001 1183X000200030005x

MONA, H. A.; MOHAMED, H. A.; HAFEZ, S. F. M. 2005. Biological and physiological effects of bioinsecticide Spinosad on the cutworm, Agrostis ipsilon (Hüfnagel). Egyptian Journal of Biological Pest Control 15: 139-145.

MONTEIRO, A. H. R. R.; GOMES, S.; GOMES, I.; QUEIROZ, P. R.; LIMA, L. H. C.; OLIVEIRA, M. R. V. 2005. Current status of the whitefly Aleurodicus dispersus as an invasive pest in the Cape Verde Islands. pp. 261-262. In: Alford, D. V.; Backhaus, G. F. (Eds.). Plant protection and plant health in Europe: Introduction and spread of invasive species, held at Humboldt University, Berlin, Germany, 9-11 June 2005, 441 p.

NAIK, M. I.; KUMAR, M.A. A.; MANJUNATHA, M.; SHIVANNA, B. K. 2010. Survey for the pests of castor and natural enemies of castor semilooper. Environment and Ecology 28: 558-563.

NANDAGOPAL, V.; RATHOD, V. 2007. Development of efficient pheromone trap for field catch of Spodoptera litura (F.) in groundnut and castor ecosystem. Journal of Applied Zoological Researches 18: 29-32.

NASS, L. L.; PEREIRA, P. A. A.; ELLIS, D. 2007. Biofuels in Brazil: An overview. Crop Science 47 (6): 2228-2237. https:// doi.org/10.2135/cropsci2007.03.0166

NAVATHA, L.; SREEDEVI, K. 2012. Insect pollinator diversity and abundance in Castor, Ricinus communis L. Current Biotica 6: 251-253.

NAVEEN KUMAR, P.; PRASAD, Y. G.; PRABHAKAR, M.; PHANIDHARA, A.; VENKATESWARLU, B. 2013. Granulovirus of semilooper, Achaea janata L. (Lepidoptera: Noctuidae): its bioefficacy and safety in mammalian toxicity tests. Journal of Biological Control 27: 99-104.

NEELANARAYANAN, P.; INDIRA, P. 2010. Effect of Calotropis gigantean leaves extract on the feeding activities of pest of castor woolly bear, Pericallia ricini. Insect Environment 16: 39-40.

NEGREIROS, J.; VENDRAMIN, J. D.; RODRIGUES, M. E. V.; MENDONCA, G. A. 1998. Comparison of the biology of the eri silkworm Philosamia ricini (Drury) (Lepidoptera, Saturniidae) on four castor bean genotypes. Revista de Agricultura (Piracicaba) 73: 155-166.

OSHAIBAH, A. A.; BADR, M. A.; HUSSEIN, H. R.; AL-GAMAL, M. M. 1986. Identification of Sathrobrota rileyi (Wals.) (Lep.Cosmopterigidae as a new record in Egypt). Agricultural Research Review 61: 273-283.

PARKMAN, P.; DUSKY, J. A.; WADDILL, V. H. 1989. Biological Studies of Liriomyza sativae (Diptera, Agromyzidae) on castor bean. Environmental Entomology 18 (5): 768-772. https://doi. org/10.1093/ee/18.5.768
PARMAR, P. D.; VYAS, H. J.; RATHOD, R. R. 2006. Bionomics of leaf hopper, Jacobiasca furcostylus (Ramakrishnan and Menon), on castor. Indian Journal of Entomology 68: 107-112.

PATEL, B. S.; PATEL, I. S. 2009. Management of shoot and capsule borer, Conogathes punctifaralis $\mathrm{L}$ in castor by intercropping. Trends in Biosciences 2 (2): 66-67.

PATEL, P. V.; ACHARYA, M. F.; GEDIA, M. V.; VYAS, H. J. 2009. Study on growing degree days and population dynamics of thrips, Scirtothrips dorsalis Hood (Thysanoptera: Thripidae) on castor. Journal of Agrometeorology 11: 79-82.

PAUL, S. K.; JHA, S.; GHOSH, M. R. 2000. Morphometric studies of Pericallia ricini F. (Arctiidae) and Euproctis fraterna (Moore) (Lymantriidae) infesting castor (Ricinus communis L.). Uttar Pradesh Journal of Zoology 20: 69-71.

POMARI, A. F.; BUENO, A. F.; BUENO, R. C. O. F.; MENEZESJR, A. O. 2013. Telenomus remus Nixon egg parasitization of three species of Spodoptera under different temperatures. Neotropical Entomology 42: 399-406. https://doi.org/10.1007/ s13744-013-0138-0

PONS, X.; LUMBIERRES, B.; GARCÍA, S.; MANETTI, P. L. 2002. Metcalfa pruinosa (Say) (Homoptera: Flatidae), ¿una plaga potencial de plantas ornamentales en espacios verdes urbanos de Cataluña? Boletín de Sanidad Vegetal Plagas 28: 217-222.

PRABHAKAR, M.; SRINIVASA, R. M.; PRASAD, Y. G. 2003. Evaluation of bio-intensive integrated pest management modules against castor semilooper, Achaea janata Linn. Indian Journal of Plant Protection 31: 56-58.

PRABHAKAR, M.; PRASAD, Y. G.; VENKATESWARLU, B. 2010. New record of Hexamermis dactylocercus Poinar and Linares (Nematoda: Mermithidae) parasitizing red hairy caterpillar, Amsacta albistriga (Walker) (Lepidoptera: Arctiidae) from India. Journal of Biological Control 14: 385-387.

RAGHAVAIAH, G. 2011. Pests of crops and their management 2011-12. Department of Entomology Agricultural College, Bapatla, Acharya N G Ranga Agricultural University, Faculty of Agriculture, the India. $177 \mathrm{p}$.

RAJASEKHAR, D. W.; RACHAPPA, V. H.; AWAKNAVAR, J. S. 1999. Role of Chrysoperla carnea Stephens and insecticides in suppression of castor mite. Insect Environment 4: 151.

RAO, P. S. 1977. New records of predatory bugs on Castor semilooper, Achaea janata L. (Lepidoptera: Arctiidae) on soybean. Current Science 44: 481-482.

RAOOF, M. A.; LAKSHMINARAYANA, M; CHANDER RAO, S. 2003. Crop Protection. pp. 50-73. In: Hegde, D. M.; Sujatha, M.; Singh, N. B. (Eds.). Castor in India. Directorate of Oilseeds Research, Rajendranagar, Hyderabad, India. 118 p.

RAVEENDRANATH, S.; KRISHNAYYA, P. V.; RAO, P. A.; MURTHY, K. V.; HUSSAINI, S. S. 2008. Bioefficacy of entomopathogenic nematodes, Steinernema carpocapsae and Heterorhabditis indica against pupae of Spodoptera litura. Indian Journal of Plant Protection 36: 288-291.

REIF, J. C.; GUMPERT, F. M.; FISCHER, S.; MELCHINGER, A. E. 2007. Impact of interpopulation divergence on additive and dominance variance in hybrid populations. Genetics 176 (3): 1931-1934. https://doi.org/10.1534/genetics.107.074146

RIBEIRO, L. do P.; COSTA, E. C. 2008. Occurrence of Erinnyis ello and Spodoptera marima in castor bean plantation in Rio Grande do Sul State, Brazil. Ciencia Rural 38 (8): 2351-2353. https:// doi.org/10.1590/S0103-84782008000800040

RIZZARDO, R. A. G.; MILFONT, M. O.; SILVA, E. M. S.; FREITAS, B. M. 2012. Apis mellifera pollination improves agronomic productivity of anemophilous castor bean (Ricinus communis). Anais da Academia Brasileira de Ciências 84 (4): 1137-1145, https://doi.org/10.1590/S000137652012005000057

ROSSI, G. D.; SANTOS, C. D.; CARVALHO, G. A.; ALVES, D. S.; PEREIRA, L. L. S.; CARVALHO, G. A. 2012. Biochemical analysis of a castor bean leaf extract and its insecticidal effects 
against Spodoptera frugiperda (Smith) (Lepidoptera: Noctuidae). Neotropical Entomology 41: 503-509. https://doi.org/10.1007/ s13744-012-0078-0

SAILAJA, M.; TARAKESWARI, M.; SUJATHA, M. 2008. Stable genetic transformation of castor (Ricinus communis L.) via particle gun-mediated gene transfer using embryo axes from mature seeds. Plant Cell Reports 27: 1509-1519. https://doi. org/10.1007/s00299-008-0580-3

SALDARRIAGA CARDONA, A.; LONDOÑO ZULUAGA, M. E.; CÓRDOBA GAONA, O. de J. 2011. Problemas fitosanitarios asociados al cultivo de higuerilla en Colombia. Corporación Colombiana de Investigación Agropecuaria, CORPOICA, Centro de Investigación La Selva, Rionegro, Antioquia, Colombia. Cartilla Divulgativa. 52 p. Available in: http://bibliotecadigital. agronet.gov.co/bitstream/11348/6461/1/Revista\%20Cultivo\%20 de\%20Higuera.pdf [Review date: December 2017]

SALIHU, B. Z.; GANA, A. K.; APUYOR, B. O. 2014. Castor oil plant (Ricinus communis L.): Botany, ecology and uses. International Journal of Science and Research 3: 2319-7064.

SARMA, A. K.; SINGH, M. P.; SINGH, K. I. 2005. Studies of insect-pests of castor in the agro-ecosistem of Manipur. Journal of Applied Zoological Researches 16: 164-165.

SARMA, A. K.; SINGH, M. P.; SINGH, K. I. 2006. Resistance of local castor genotypes to Achaea janata Linn. and Spodoptera litura Fabr. Journal of Applied Zoological Researches 17: 179181.

SATYAGOPAL, K.; SUSHIL, S. N.; JEYAKUMAR, P.; SHANKAR, G.; SHARMA, O. P.; BOINA, D. R.; SAIN, S. K.; RAM, A.; KAPOOR, K. S.; SANJAY, A.; SUBHASH, K.; PATNI, C. S.; SURESH, D. E.; RAJASHEKARAPPA, K.; LAKSHMINARAYANA, M.; NARAYANASWAMY, H.; SHIVANNA, B. K. 2014. AESA based IPM package for castor. National Institute of Plant Health Management. Department of Agriculture and Cooperation, Ministry of Agriculture. Government of India. Rajendranagar, Hyderabad, Telangana, India. $384 \mathrm{p}$.

SATYANARAYANA, J.; SING, T. V. K. 2003. Outbreak of Helicoverpa armigera (Hubner) on castor in Southern Telangana Region of Andhra Pradesh. Insect Environment 8: 176-177.

SATYANARAYANA, J.; BALLAL, C. R.; RAO, N. S. 2005. Evaluation of egg parasitoid, Telenomus remus Nixon and larval parasitoid, Campoletis chlorideae Uchida on Spodoptera litura (Fabricius) in castor. Indian Journal of Plant Protection 33: 26-29.

SAVY, A. F. 2005. Mamona tecnologia agrícola. Campinas-SP, Brasil. EMOP. 105 p.

SEVERINO, L. S.; MILANI, M.; DE ALMEIDA, M, C. R.; DE SOUZA, G. T. M.; CARDOSO, G. D. 2006. Avaliacão da produtividade e teor de óleo de dez genótipos de mamoneira cultivados em altitude inferior a 300 metros. Revista Ciência Agronomica 37: 188-194.

SEVERINO, L. S.; FREIRE, M. A. O.; LUCENA, A. M. A.; VALE, L. S. 2010. Sequential defoliations influencing the development and yield components of castor plants (Ricinus communis L.). Industrial Crops and Products 32 (3): 400-404. https://doi. org/10.1016/j.indcrop.2010.06.007

SEVERINO, L. S.; AULD, D. L.; BALDANZI, M.; CÂNDIDO, M. J. D.; CHEN, G.; CROSBY, W.; TAN, D.; HE, X.; LAKSHMAMMA, P.; LAVANYA, C.; MACHADO, O. L. T.; MIELKE, T.; MILANI, M.; MILLER, T. D.; MORRIS, J. B.; MORSE, S. A.; NAVAS, A. A.; SOARES, D. J.; SOFIATTI, V.; WANG, M. L.; ZANOTTO M. D.; ZIELER, H. 2012. A review on the challenges for increased production of castor. Agronomy Journal 104 (4): 853-880. https://doi.org/10.2134/ agronj2011.0210

SHALABY, F. F.; IBRAHIM, A. A.; KARES, E. A. 1988. Effect of parasitism by Microplitis rufiventris Kok. on the susceptibility of Spodoptera littoralis (Boisd.) larvae to bolstar 702 E.C. Bulletin of the Entomological Society of Egypt, Economic Series 15: $165-172$.
SHARMA, A.; SINGH, R. 2002. Oviposition preference of cotton leafhopper in relation to leaf-vein morphology. Journal of Applied Entomology 126 (10): 538-544. https://doi.org/10.1046/ j.1439-0418.2002.00697.x

SHARMA, M. L.; SHUKLA, A.; REDDY, R. K. 1995. Field testing of castor cultivars for their yield potential and resistance against shoot and capsule borer, Dichocrocis punctiferalis Guenea. Crop Research (Hisar) 10: 54-58.

SINGH, A. S.; KUMARI, S.; MODI, A. R.; GAJERA, B. B.; NARAYANAN, S.; KUMAR, N. 2015. Role of conventional and biotechnological approaches in genetic improvement of castor (Ricinus communis L.). Industrial Crops and Products 74: 55-62. https://doi.org/10.1016/j.indcrop.2015.05.001

SINGH, G.; GREWAL, G. S. 1982. Chemical control of the Bihar hairy caterpillar Diacrisia obliqua Walker, on castor and sesame. International Journal of Entomology, India 1: 69-71.

SINGH, S.; SINGH, S. K.; SUDHAKAR, R. 2006. Comparative performance of different pest management treatments for castor+pigeonpea intercropping system under rainfed conditions. Research on Crops 7: 548-551.

SINGH, S.; SINGH, S. K.; SUDHAKAR, R. 2008. Validation of integrated pest management module for castor and pigeonpea intercropping system for rainfed agroecosystem. Pesticide Research Journal 20: 217-220.

SINGH, T. V. K.; SINGH, K. M.; SINGH, R. N. 1991. Host range of groundnut jassid, Empoasca kerri Pruthi. Indian Journal of Entomology 53: 1-17.

SINGH, U. D.; AGARWAL, D. P.; PANDEY, P. N. 1989. Eclipta alba and Euphorbia hirta as new food plants and foci of infestation of Amsacta moorei Butl. (Lepidoptera: Arctiidae). Bulletin of Entomology (New Delhi) 30: 238-239.

SOARES, J. J.; ARAÚJO, L. H. A.; BATISTA, F. A. S. 2001. Pragas e seu controle. pp. 213-227. In: Azevedo, D. M. P.; Beltrão, N. E. M. (Eds.). O agronegócio da mamona no Brasil. Embrapa Algodão/Emrapa Informação Tecnológica, Campina Grande, Brasília, Brazil. 350 p.

SOUZA-SILVA, M.; FONTENELLE, J. C. R.; MARTINS, R. P. 2001. Seasonal abundance and species composition of flowervisiting flies. Neotropical Entomology 30 (3): 351-359. https:// doi.org/10.1590/S1519-566X2001000300002

SPAIN, L. A. 1940. Some reactions of grasshoppers to castor bean plants. Iowa State College Journal Science 14: 353-355.

SRINIVASA RAO, M.; RAMA RAO, C. A.; SRINIVAS, K.; PRATIBHA, G.; VIDYA SEKHAR, S. M.; SREE VANI, G.; VENKATESWARLU, B. 2012. Intercropping for management of insect pests of castor, Ricinus communis, in the semi-arid tropics of India. Journal of Insect Science 12 (1): 1-10. https:// doi.org/10.1673/031.012.1401

SUGANTHY, M. 2007. Survey and monitoring the incidence of pests of castor. The Madras Agricultural Journal 94: 133-135.

SUGANTHY, M. 2010. Integrated pest management strategies against castor defoliators. The Madras Agricultural Journal 97 (7/9): 278-280.

SUJATHA, M.; VIMALA DEVI, P. S.; REDDY, T. P. 2011. Insect pests of castor (Ricinus communis L.) and their management strategies. pp. 177-198. In: Dashavantha Reddy, V.; Nagaraja Rao, P.; Venkateswara Rao, K. (Eds.). Pests and pathogens: Management Strategies. BS Publications, CRC Press, India, $590 \mathrm{p}$.

TURLINGS, T. C. J.; WÄCKERS, F. 2004. Recruitment of predators and parasitoids by herbivore-injured plants. pp. 21-75. In: Cardé, R. T.; Millar, J. G. (Eds.). Advances in insect chemical ecology. Cambridge University Press. Cambridge University Press. 352 p. https://doi.org/10.1017/CBO9780511542664.003

USHA RANI, P. 2009. Sensillary morphology on the rostral apex and their possible role in prey location behaviour of the carnivorous stinkbug, Eocanthecona furcellata (Wolff) (Heteroptera: Pentatomidae). Acta Zoologica (Stockholm) 90 (3): 246-253. https://doi.org/10.1111/j.1463-6395.2008.00346.x 
USHA RANI, P.; PRATYUSHA, S. 2014. Role of castor plant phenolics on performance of its two herbivores and their impact on egg parasitoid behaviour. BioControl 59: 513-524. https://doi. org/10.1007/s10526-014-9590-y

USHA RANI, P.; RAJASEKHARREDDY, P. 2009. Toxic and antifeedant activities of Sterculia foetida (L.) seed crude extract against Spodoptera litura (F.) and Achaea janata (L.). Journal of Biopesticides 2: 161-164.

USHA RANI, P.; SUDHEER, S. D.; PADMINI, G.; LAVANYA, C. 2006. Nutrient-allelochemical interactions of castor, Ricinus communis (L.) plants, resistant and susceptible to infestation of green leaf hopper, Empoasca flavescens (Fabr.). Journal of Applied Zoological Researches 17: 1-8.

VANDENBORRE, G.; SMAGGHE, G; VAN DAMME, E. J. M. 2011. Plant lectins as defense proteins against phytophagous insects. Phytochemistry 72 (13): 1538-1550. https://doi. org/10.1016/j.phytochem.2011.02.024

VARÓN, E. H.; MOREIRA, M. D.; CORREDOR, J. P. 2010. Efecto de Corythucha gossypii sobre las hojas de higuerilla: criterios para su muestreo y control con insecticidas. Corpoica Ciencia y Tecnología Agropecuaria 11 (1): 41-47. https://doi.org/10.21930/ rcta.vol11 num1 art:193

VIMALA DEVI, P. S. V.; SUDHAKAR, R. 2006. Effectiveness of a local strain of Bacillus thuringiensis in the management of castor semilooper, Achaea janata on castor (Ricinus communis). Indian Journal of Agricultural Sciences 76: 447-449.

WÄCKERS, F. L.; ZUBER, D.; WUNDERLIN, R.; KELLER, F. 2001. The Effect of herbivory on temporal and spatial dynamics of foliar nectar production in cotton and castor. Annals of Botany 87 (3): 365-370. https://doi.org/10.1006/anbo.2000.1342

WANG, X. S.; CHEN, Q. Z.; ZHANG, S. Z.; LIU, T. X. 2016. Parasitism, host feeding and immature development of Encarsia formosa reared from Trialeurodes vaporariorum and Bemisia tabaci on Trialeurodes ricini. Journal of Applied Entomology 140 (5): 346-352. https://doi.org/10.1111/jen.12271

WATERS, T.; CHIRIKIAN, D.; CARMONA-GALINDO, V. D. 2014. Insect visitation of peduncular and petiolar extrafloral nectar glands on castor bean (Ricinus communis L.) plants in southern California. Journal of Evolutionary Biology Research 6 (2): 5-8. https://doi.org/10.5897/JEBR2014.0058
WENE, G. P. 1933. Injurious insects found on castor beans. Journal of Economic Entomology 48 (1): 110. https://doi.org/10.1093/ jee/48.1.110

WOLOOTT, G. N. 1917. Report of the entomologist. Fifth Rept. Bd. Comm. Agr. P. R. for the period from 1st July, 1915 to 30th June, 1916.

YADAV, R.; YADAV, N.; YADAV, R.; KATIYAR, R. R. 2010. Natural parasitization by certain parasitoids on the pests of field crops. International Journal of Plant Protection 3: 408-409.

YASUR, J.; MATHUR, K.; RANI, P. 2009. Effects of herbivore feeding on biochemical and nutrient profile of castor bean, Ricinus communis L. plants. Allelopathy Journal 24: 131-142.

YLLA, J.; MACIÀ, R.; HUERTAS DIONISIO, M. 2008. Pirálidos y Crámbidos detectados en Almería, España (Lepidoptera: Pyraloidea). SHILAP Revista de Lepidopterología 36: 191-204.

YOUNIS, A. M. 1992. Effect of constant temperatures on development and survival of the immature stages of the black cutworm Agrotis ipsilon (Hüfnagel) Lepidoptera: Noctuidae. Assiut Journal of Agricultural Sciences 23: 291-301.

ZHANG, H. J.; DUAN, G. Q.; ZHANG, Z. B.; LIANG, Z. J.; ZHIANG, D. M.; XU, Q.; WANG, X. M.; XU, A. L.; LIU, Z. 2006. Effect of leaf mining by Liriomyza sativa larvae Photosynthesis of some crops. Acta Entomologica Sinica 40: 100-105.

\section{Origin and funding}

This work was part of a project on pests of Ricinus communis in Mexico and was supported by Secretaría de Agricultura, Ganadería, Desarrollo Rural, Pesca y Alimentación (SAGARPA, Mexico).

\section{Author contribution}

Guillermo López-Guillén, Jaime Gómez Ruiz and Juan F. Barrera defined the content of the study, conducted the literature review and wrote the manuscript. All authors read and approved the final manuscript. 